\title{
A PRECARIZAÇÃO DO DIREITO HUMANO FUNDAMENTAL AO TRABALHO NAS ORGANIZAÇÕES SOCIAIS DE SAÚDE ${ }^{1}$
}

THE PRECARIOUS CONDITIONS OF THE FUNDAMENTAL HUMAN RIGHT TO WORK IN SOCIAL
HEALTH ORGANIZATIONS

Elda Coelho de Azevedo Bussinguer ${ }^{2}$

Shayene Machado Salles ${ }^{3}$

\begin{abstract}
Resumo: Propõe-se investigar a problemática que envolve a fragilidade dos vínculos trabalhistas na sociedade contemporânea, tendo como foco de análise a precarização do trabalho nas Organizações Sociais de Saúde (OSSs). Nessa perspectiva, a análise da categoria Foucaultiana "Governamentalidade neoliberal" tem em vista a indicação da conformidade que as políticas características dessa razão de governo possuem com a política de gestão de "recursos humanos", pautada na formalização de vínculos precários de trabalho adotada por OSSs. Trata-se de pesquisa qualitativa, do tipo descritiva e exploratória, realizada mediante abordagem teórica fundamentada em dados secundários. Objetiva-se analisar como o trabalho humano se estabelece sob a ótica de uma racionalidade de governo mercadológica que o fragiliza tanto pela precariedade quanto pela flexibilização; e identificar as práticas de estímulo ao trabalho precário no interior das OSSs. Portanto, temos como objeto de estudo as relações de trabalho estabelecidas no
\end{abstract}

interior das OSSs, sobre as quais, segundo a hipótese apresentada neste trabalho, incidem relações de mercado, decorrentes da governamentalidade neoliberal, (re)produtora de relações precárias e flexíveis. A pesquisa alicerça-se na premissa da assunção das OSSs como estratégia de governo articulada, na década de 1990, no contexto da reforma econômica e administrativa do aparelho estatal. Nesse sentido, a partir da aproximação entre as características da governamentalidade neoliberal e a onda de reformas realizadas nos anos 1990, identifica-se a interligação com uma razão de governo neoliberal. Concluiu-se que as OSSs podem ser compreendidas como uma técnica de gestão, uma estratégica de governo, viabilizadora de controles biopolíticos no contexto laboral, mediante a imposição do governo do mercado.

Palavras-chave: Direito Humano Fundamental ao trabalho. Michel Foucault. Governamentalidade neoliberal. Trabalho precário. Organização Social de Saúde.

\footnotetext{
1 Este artigo constitui-se como parte integrante do projeto de pesquisa, financiado pelo CNPq, intitulado Complexo Econômico Industrial da Saúde (CEIS), inovação e dinâmica capitalista: desafios estruturais para a construção do Sistema Universal de Saúde no Brasil.

2 Doutora em Bioética pela Universidade de Brasília; Mestre em Direitos e Garantias Fundamentais pela Faculdade de Direito de Vitória; Livre Docente pela Universidade do Rio de Janeiro; elda.cab@gmail.com; https://orcid.org/0000-0003-43034211

3 Mestre e doutoranda em Direito pelo Programa de Pós-Graduação em Direitos e Garantias Fundamentais da Faculdade de Direito de Vitória; Membro do Grupo de Estudos, Pesquisa e Extensão em Políticas Públicas, Direito à Saúde e Bioética; Rua Juiz Alexandre Martins de Castro Filho, 215, Santa Lucia, 29056-295, Vitória, Espírito Santo, Brasil; shayenemachado@ gmail.com; https://orcid.org/0000-0002-0266-0745
} 


\begin{abstract}
It is proposed to investigate the problematic that involves the fragility of the employment relationships in the contemporary society, having as a focus of analysis the precariousness of the work in the Social Organizations of Health (OSSs). In this perspective, the analysis of the Foucauldian category "Neo-liberal governmentality", it is aimed at indicating the conformity that the characteristic policies of this government reason have with the management policy of "human resources", based on the formalization of precarious labour relations adopted by OSSs. It is a qualitative, descriptive, and exploratory research, carried out through a theoretical approach based on secondary data. The objectives are to analyze how the human labour is established under the optics of a market-oriented rationality that weakens it both by precariousness and flexibility; and to identify the practices to stimulate precarious labour within the OSS. Therefore, the object of study are the labor relations established within the OSSs. Concerning them, according to the hypothesis presented in this study, there are the market relations, arising from neoliberal governmentality, (re)producer of precarious and flexible relations. The research is based on the assumption of the OSSs as an articulated government strategy, in the 1990s, in the context of the economic and administrative reform of the state apparatus. In this sense, based on the approximation between the characteristics of neoliberal governmentality and the wave of reforms carried out in the 1990s, the interconnection with a neoliberal government reason is identified. It was concluded that the OSSs can be understood as a management technique, a government strategy, which enables biopolitical controls in the labor context, through the imposition of the market governance.
\end{abstract}

Keywords: Fundamental Human Right to work. Michel Foucault. Neo-liberal governmentality. Precarious work. Social Health Organization.

\title{
Introdução
}

No cenário do neoliberalismo globalizado as exigências do mercado sinalizam a impossibilidade de se ignorarem as influências exercidas pelo capital sobre práticas, políticas e ações institucionais nos campos laboral e da saúde, ambos concebidos como setores de investimento e de desenvolvimento.

Nessa perspectiva, considerando que os processos de exploração e de expropriação do trabalho humano não se desenvolvem dissociados da conjuntura em que são forjados, importa direcionar-se para o enfrentamento de crises congênitas do modelo de produção capitalista que os sustentam, como a crise anunciada pela tendência expansionista do trabalho precário no Brasil.

Ao se referir ao trabalho precário, alude-se àquele cujo caráter de incerteza, de instabilidade, de imprevisibilidade e de indignidade reforça a assunção dos riscos empregatícios por parte do trabalhador, uma vez que sobre este recai um ônus desproporcional e abusivo, sobretudo se considerarmos o que o leva a suportá-lo: a subsistência e, mais que isso, sua inclusão social.

Uma espécie de princípio da alteridade (art. $2^{\circ}$ da Consolidação das Leis Trabalhistas) às avessas que, a despeito de sua manifesta afronta a direitos trabalhistas, naturaliza-se nas relações laborais mediante práticas formalmente legítimas, a exemplo da terceirização e da contratação por tempo parcial, mas também mediante a prática de ilegalidades recorrentes, como a contratação por meio de falsas pessoas jurídicas, o não registro do trabalhador em sua carteira de trabalho ou, até mesmo, a anotação irregular com data adversa da realidade, etc. 
Há um rol não taxativo de irregularidades que atestam a precariedade das relações de trabalho em sociedades marcadas pelo modelo econômico neoliberal e, consequentemente, pela produção de efeitos aparentemente indeléveis. Trata-se, portanto, de modo generalista, de anunciar uma tendência à flexibilidade dos vínculos de trabalho que, nesta análise, focalizará especialmente o setor saúde em razão do recorte metodológico proposto.

Estudos existentes apontam para alteração nos padrões de relacionamento entre o público e o privado em saúde no que tange às relações de trabalho que passaram a caracterizar as contratações realizadas, como direto desdobramento das reformas ocorridas na década de 1990, visando à redução de gastos públicos.

Desse modo, se por um lado, sob um viés macroeconômico, foi possível observar nos anos 1990 um expansionismo positivo no que se refere à rede de serviços de saúde e, consequentemente, ao aumento de postos de trabalho, sobretudo em razão do primado da descentralização (PIERANTONI; VARELLA, 2008, p. 537), por outro lado, a prática de contratualizações flexíveis, isto é, frágeis e desprotetivas em relação ao trabalhador, pode ser percebida pelo aumento da informalidade nos vínculos de trabalho como produto dos impactos da desregulamentação e da desestruturação do mercado de trabalho no Brasil observados naquele período (GIRARDI; CARVALHO, 2002; MACHADO, 2000b).

As pesquisas que analisam o comportamento do mercado assalariado em saúde a partir do regime dos trabalhadores (celetista ou estatutário) constatam a predominância do regime estatutário de 1990 a 1995. Em contrapartida, verificam um crescimento vertiginoso de vínculos de emprego regidos pela Consolidação das Leis Trabalhistas (CLT) a partir do ano 1995 até os anos 2000 (GIRARDI; CARVALHO, 2002, p. 20).

Tais considerações sugerem que a compreensão do expansionismo do trabalho precário no Brasil pressupõe o aprofundamento no alicerce institucional que pode ser apontado como legitimador de relações de trabalho, cada vez mais, flexíveis e desregulamentadas.

Sob essa perspectiva, a desregulação, a privatização e o consequente desmantelamento de proteções sociais são produtos de uma lógica lucrativa estimulada pela pauta neoliberal, composta por propostas políticas estimuladoras da abertura do mercado ao capital estrangeiro, da privatização de empresas e de serviços públicos.

A reforma gerencial do Estado, ocorrida na década de 1990, compreendida como corolário do dinamismo mercadológico, fomentou a criação de organismos não estatais que passaram a desempenhar gestão de serviços, de recursos, de atividades eminentemente públicas, a exemplo das Organizações Sociais de Saúde (OSSs).

No que concerne à estrutura jurídica das Organizações Sociais de Saúde, importa esclarecer que a Constituição Federal de 1988, no art. 196, estabeleceu que a saúde é dever do Estado, no entanto excepcionou a regra ao possibilitar que a iniciativa privada preste serviços públicos de modo complementar. Trata-se de previsão que, ao facultar a Administração Pública, a delegação de serviços públicos ao privado contrariou princípios basilares do Sistema Único de Saúde, sobretudo se 
considerar que a delegação de serviços públicos de saúde às Organizações Sociais tem se manifestado como regra nos estados e municípios, no âmbito de hospitais, do Pronto Atendimentos, de Postos de Saúde, de Hemocentros, etc. (PERIM, 2014, p. 61).

Nesse contexto, o surgimento das Organizações Sociais de Saúde (OSSs) no Brasil corresponde ao período em que o Estado foi reconfigurado com vistas ao desenvolvimento econômico, na década de 1990, especialmente de 1995 a 2002, quando o Plano Diretor de Reforma do Aparelho do Estado (PDRAE) alicerçou a transferência de recursos públicos. Em 1998, a legitimação institucional foi formalizada com o sancionamento de legislação específica, voltada para a criação e regulamentação da atividade das OSSs, a Lei n. 9637/1998.

A par dessas considerações preliminares, convém esclarecer que a proposta central deste artigo consiste em analisar a problemática que envolve a fragilidade dos vínculos trabalhistas na sociedade contemporânea, tendo como foco de análise a precarização do trabalho nas OSSs. Tratase de pesquisa qualitativa, do tipo descritiva e exploratória, realizada mediante abordagem teórica fundamentada em dados secundários.

Nessa perspectiva, a análise da categoria Foucaultiana Governamentalidade neoliberal tem em vista a indicação da conformidade que as práticas e políticas características dessa razão de governo possuem com a política de gestão de "recursos humanos", pautada na formalização de vínculos precários de trabalho adotada por OSSs. Apresenta-se, portanto, como hipótese a afirmação de que sobre as relações de trabalho estabelecidas em tais organizações incidem relações de mercado decorrentes da governamentalidade neoliberal, (re)produtora de relações precárias e flexíveis.

Tendo como referencial teórico a categoria Foucaultiana Governamentalidade neoliberal, ${ }^{4}$ este artigo foi estruturado nas três seguintes sessões: 1) Complexidades e tendências do mercado de trabalho em saúde e das relações laborais no setor a partir dos anos 1990; 2) Relações entre o público e o privado no âmbito laboral: o (des)valor do trabalho humano na governamentalidade neoliberal; e 3) A precariedade laboral nas Organizações Sociais de Saúde: o controle biopolítico desencadeador da flexibilidade das relações de trabalho.

\section{Governamentalidade neoliberal em Michel Foucault: 0 ordoliberalismo alemão e o neoliberalismo norte-americano}

A governamentalidade neoliberal, categoria estruturante deste artigo, será analisada, nesta seção, a partir da obra Nascimento da Biopolítica (2008a), de Michel Foucault, a qual permitirá a identificação do relacionamento entre o mercado e o Estado, bem como dos elementos caracterizadores da aludida razão de governo. Na referida obra, Foucault direciona sua análise à compreensão da manifestação da racionalidade neoliberal na Alemanha, por meio do ordoliberalismo, e nos Estados

\footnotetext{
4 A ênfase do estudo, sem prejuízo de análise das outras obras do autor, dirige-se, predominantemente, a dois cursos ministrados por Michel Foucault, a saber: Segurança, Território e População (2008b) e Nascimento da Biopolítica (2008a).
} 
Unidos, por meio do neoliberalismo norte-americano, nos quais, segundo Foucault (2008a, p. 107), têm-se as principais formas de apresentação do programa neoliberal.

Considerando a a proximação da governamentalidade neoliberal com as práticas de trabalho precário no interior das Organizações Sociais de Saúde, optou-se por realizar neste artigo um breve esboço das considerações teóricas de Foucault que permitem a caracterização da racionalidade neoliberal na Alemanha e nos Estados Unidos.

\subsection{0 ordoliberalismo alemão}

Foucault (2008a, p. 179-180) esclarece que o neoliberalismo, seja alemão seja norteamericano, geralmente é traduzido a partir de três pontos de partida: o econômico, o sociológico e o político. Nesse sentido, pautando-se na perspectiva econômica, o neoliberalismo pode ser compreendido como um retorno das teorias econômicas desenvolvidas pelo liberalismo. Já sob a ótica sociológica, entende-se o neoliberalismo como o processo de estabelecimento de relações mercadológicas na sociedade. E, finalmente, tendo como foco um olhar sobre a dimensão política, o neoliberalismo pode ser assumido como o revestimento do Estado para uma intervenção generalizada e administrativa em seu interior.

No entanto, a despeito da apreensão neoliberal realizada por meio dos pontos de vista econômico, sociológico e político, a definição adotada por Foucault (2008a, p. 181) do que seja neoliberalismo pode ser traduzida pelo objetivo de promover a regulação do exercício do poder político por meio dos princípios da economia de mercado ou, ainda, em palavras mais diretas, pela assunção de uma arte de governar segundo tais princípios, razão pela qual o liberalismo, em seu sentido clássico, necessitou passar por uma sistemática transformação.

Foucault (2008a, p. 184) define a ação governamental característica dos neoliberais remontando a três exemplos: a questão do monopólio, o problema da ação econômica e o problema da política social.

No que tange à formação do monopólio, para os neoliberais esta não consiste em um fenômeno natural, nem mesmo espontâneo, decorrente da concorrência. Pelo contrário, como mencionamos anteriormente, assim como a concorrência não é um dado da natureza, tampouco será a tendência monopolista, a qual importa em obste ao funcionamento dos mecanismos da concorrência, justificando a necessidade do recurso a práticas impeditivas a sua ocorrência mediante a criação, no âmbito institucional, de uma moldura antimolopolista. Foi dessa forma que o Estado alemão, sem que houvesse uma direta intervenção no mercado, criou impedimentos à prática do monopólio por meio da moldura legislativa e, consequentemente, viabilizou a regulação do mercado e a preservação da concorrência (FOUCAULT, 2008a, p. 186-189). 
Notamos, portanto, que no neoliberalismo a intervenção realizada com vistas a coibir o monopólio tem como premissa a observância de uma moldura política definidora do modo como se realizará a ingerência do governo sobre o mercado.

Desse modo, sem que se interfira diretamente no mercado, este será regulado por meio da "moldura institucional antimonopolista", que compreende tudo aquilo que o circunscreve, do que se situa ao redor da economia: a população, o regime jurídico, as atividades do próprio governo, etc. A regulação ocorrerá mediante a intervenção no entorno do mercado, sobre os condicionantes da economia de mercado, sobre a moldura (FOUCAULT, 2008a, p. 193).

No que diz respeito ao domínio da ação econômica, o governo neoliberal caracterizouse por realizar intervenções em elementos que tangenciam a economia. Não estamos tratando de quaisquer intervenções. Há intervenções boas e ruins, sendo estas últimas as que se dirigem a regular o mercado intervindo diretamente em seu funcionamento, a exemplo das intervenções sobre o preço ou sobre determinado setor da economia. A intervenção neoliberal, para além da interferência do domínio econômico, propõe-se a intervenção sobre a sociedade visando à regulação do mercado (FOUCAULT, 2008a, p. 192-193).

Trata-se, portanto, de um governo que não é estritamente econômico, mas de um governo que, ao impor a observância de condicionantes, de elementos, de leis exteriores ao mercado que são responsáveis por regulá-lo, manifesta-se como um governo de sociedade (FOUCAULT, 2008a, p. 199).

A atuação governamental que caracteriza o neoliberalismo, ao intervir sobre o que se situa ao redor do mercado, isto é, ao aderir à "política de moldura", interferirá no regime jurídico e na sociedade, sobretudo porque o campo do Direito viabilizará a regulação econômica por meio de leis que regerão o mercado e a sociedade, e esta última será normalizada segundo o modelo da empresa.

Nesse contexto, Foucault (2008a, p. 200-201) esclarece que a sociedade concorrencial de que tratam os neoliberais difere da sociedade de consumo, da sociedade das trocas e da sociedade de mercadorias aludida por Marx. Trata-se, pois, de uma sociedade orientada pelos mecanismos da concorrência, o que resultará em um modelamento social pautado na empresa e, consequentemente, na formação de um sujeito social que atua em paridade com esse contexto. Daí dizer-se que "O homo economicus que se quer reconstituir não é o homem da troca, não é o homem consumidor, é o homem da empresa e da produção."

Assim, na medida em que se concebe a empresa como um "poder enformador da sociedade", multiplicam-se as formas de manifestação desse modelo empresarial, seja na propriedade privada, na casa individual, na gestão de comunidades de vizinhança, haverá elementos advindos da lógica empresarial (FOUCAULT, 2008a, p. 203).

Como consequência direta de uma sociedade forjada em conformidade com o modelo empresarial tem-se a maximização do intervencionismo jurídico, correlacionando a lógica do mercado e o Direito, como facetas complementares, ou, nas palavras de Foucault (2008a, p. 204), como "[...] as duas faces de um mesmo fenômeno." 
As relações empresariais estabelecidas socialmente são vislumbradas como potenciais estimuladoras da atuação do Judiciário, intervindo na regulação do mercado na medida em que este desempenha sua atividade jurisdicional sobre os contenciosos. Nesse contexto, Foucault (2008a, p. 204) externaliza o embrincamento jurídico na esfera empresarial esclarecendo que

[...] entre uma sociedade indexada na forma da empresa [... ${ }^{* *}$ e uma sociedade em que o principal serviço público é a instituição judiciária, há um vínculo privilegiado. Quanto mais você multiplica a empresa, [...] quanto mais você multiplica os centros de formação de uma coisa como uma empresa, [...], mais , é claro, você multiplica as superfícies de atrito entre uma dessas empresas, mais você multiplica as ocasições de contenciosos, mais você multiplica também a necessidade de uma arbitragem jurídica.

Portanto, na governamentalidade neoliberal, o Direito atuará paralelamente e em conformidade com a economia concorrencial. O Estado de Direito e os princípios que dele decorrem serão aplicados na ordem econômica, impondo juridicamente a observância e o respeito às leis de mercado.

O rule of law e o Estado de Direito formalizam a ação do governo como um prestador de regras para um jogo econômico em que os únicos parceiros e os únicos agentes reais devem ser os indivíduos ou, digamos, se preferirem, as empresas. Um jogo de empresas regulado no interior de uma moldura jurídico institucional garantida pelo Estado [...] (FOUCAULT, 2008a, p. 238).

O exercício do poder político estatal se realizará por intermédio de regras jurídicas que visam à regulação econômica, condicionando a ação do governo e dos indivíduos, concebidos como unidade empresarial, em conformidade com os fundamentos viabilizadores do jogo econômico.

O rule of law, isto é, a ideia de uma organização política submetida ao Direito, servirá de base para o avanço do capitalismo de mercado e para a consolidação de elementos que caracterizam seu funcionamento, a exemplo da liberdade individual, da propriedade privada, do autointeresse, da competitividade, do enriquecimento, da meritocracia. O Estado, ao mesmo tempo em que será limitado por liberdades fundamentais, será a entidade jurídica responsável por assegurá-las socialmente.

Sob essa ótica, afirma-se que a governamentalidade neoliberal garantirá uma moldura jurídico-institucional condizente com a economia de mercado.

No âmbito da política social, é importante observar que, de acordo com os neoliberais, em manifesta oposição à política social socialista, os alemães são partidários a uma "política social individual" que, como o próprio nome sugere, caracteriza-se por individualizar a política social ao invés de coletivizá-la, considerando que os riscos sociais devem ser assumidos individualmente e que a política social fundamental a ser assumida pelo governo consiste em assegurar o crescimento econômico. Este será o viabilizador de condições para que os indivíduos possam obter uma renda capaz de lhes permitir o custeio de seguros individuais, o acesso à propriedade privada, etc. Trata-se do que Müller-Armack denominou "economia social de mercado", mas que, no entanto, tal definição 
de política social sob a ótica neoliberal não logrou êxito na Alemanha, a qual, em contrapartida, foi fortemente influenciada por elementos do socialismo bismarckiano ou, até mesmo, da economia keynesiana (FOUCAULT, 2008a, p. 197-198).

A despeito do não implemento das definições que sustentam a perspectiva neoliberal no campo da política social, a teoria desenvolvida pelos ordoliberais serviu de base e de influência para outros países nos quais houve adesão a essa "política social privatizada" (FOUCAULT, 2008a, p. 198-199).

O ordoliberalismo alemão constituiu-se como uma racionalidade governamental que foi difundida por outros países do Ocidente voltados ao desenvolvimento do capitalismo, a exemplo dos Estados Unidos, do qual trataremos visando à identificação das características que lhe são próprias e que nos permitem afirmar a proeminência de um neoliberalismo tipicamente norte-americano.

\subsection{0 neoliberalismo norte-americano}

A análise do neoliberalismo norte-americano é realizada por Foucault (2008a, p. 106) a partir da política do New Deal, da crítica da política de Roosevelt e, após a Segunda Guerra Mundial, da oposição ao intervencionismo federal e aos programas assistenciais implementados por administrações democratas.

Nesse sentido, afirmar-se que, assim como na Alemanha, o neoliberalismo norteamericano foi marcado por sua forte oposição ao intervencionismo econômico e social, tendo como peculiaridade o fato de tratar de políticas tipicamente estadunidenses, a exemplo do New Deal.

Como desdobramento da crise de 1929, no período compreendido entre 1933 e 1937, o New Deal se caracterizou pela implementação de programas e de políticas marcadas pelo intervencionismo econômico estatal, fundamentais para que se constituísse o que poderíamos chamar de um Estado de Bem-Estar Social nos moldes estadunidenses. Foram promovidas ações de cunho econômico e social, como o controle de preços e da produção empresarial, o estímulo da produção de gêneros agrícolas, os investimentos em obras públicas, a redução da jornada laboral e a criação da previdência e do seguro-desemprego.

A crítica liberal direcionada ao intervencionismo do Estado tanto no âmbito econômico, quanto no campo social, pode ser apontada como um pressuposto elementar e, portanto, comum às distintas manifestações do neoliberalismo, compreendido tanto sob o molde alemão, quanto sob a ótica estadunidense.

No entanto, a despeito de comungarem tal pressuposto, nota-se, ao observar as circunstâncias políticas e históricas de cada país, que a racionalidade governamental assumiu dimensões específicas e complementares a cada contexto, fato que nos permite afirmar, preliminarmente, que a governamentalidade neoliberal norte-americana avançou sobremaneira em relação ao que se desenvolveu na Alemanha, sobretudo pelo neoliberalismo ter sido assumido nos Estado Unidos como uma abordagem não restritiva à análise das tecnologias de governo. 
Nesse sentido, para além da governamentalidade, a apreensão do neoliberalismo norteamericano manifesta sua complexidade no tocante a sua dimensão de "reivindicação global, multiforme, ambígua" e, mais que isso, no que tange a sua percepção metodológica em relação à análise econômica e sociológica (FOUCAULT, 2008a, p. 301). Há, portanto, que considerarmos como característica do neoliberalismo estadunidense sua assimilação como uma mundividência e, simultaneamente, como método ou instrumento de ação.

Reforçando a oposição entre o liberalismo social alemão e o neoliberalismo norteamericano, Candiotto (2010, p. 41-42) esclarece que enquanto o primeiro se caracteriza por uma economia de mercado pautada na regulação dos preços pelo próprio mercado, o segundo ultrapassa essa dimensão da fixação dos preços, passando a abranger searas não econômicas, a exemplo da família, da educação, do controle de natalidade, da saúde, do trabalho e da deliquência.

Ou seja, de acordo com os neoliberais norte-americanos, a regulação realizada pelo mercado afetará também fatores exógenos à economia, isto é, questões atinentes aos problemas e à vida da população.

Sob essa perspectiva, entende-se como herança da racionalidade governamental neoliberal norte-americana que "[...] o mercado competitivo passou a ser a nova referência não somente da economia, mas de todas as demais instâncias sociais e, além delas, da própria existência individual." (CANDIOTTO, 2010, p. 42). Da regulação dos preços à regulação social, passaremos a nos aprofundar acerca de uma racionalidade de governo viabilizadora do controle da vida dos indivíduos.

O neoliberalismo norte-americano permite vislumbrar avanços no que diz respeito à formulação da Teoria do Capital Humano, bem como no que tange à constituição de um programa de análise da criminalidade e da delinquência, assuntos dos quais passaremos a tratar.

Convém ressaltar que, seja sobre a análise da Teoria do Capital Humano, seja sobre o programa de análise da criminalidade e da delinquência, em ambas abordagens há em comum o fato de se apresentarem como leituras mercadológicas, respectivamente, do comportamento humano e da justiça penal e podem ser apontadas como herança dos estudiosos da Escola de Chicago, a exemplo de Theodore Schultz e de George Stigler e de suas contribuições para o desenvolvimento teórico da Teoria do Capital Humano (COSTA, 2009, p. 174).

O neoliberalismo norte-americano caracterizou-se por introduzir elementos que, segundo o liberalismo clássico, seriam exteriores à análise econômica, a exemplo da analítica do trabalho e, especialmente, da Teoria do Capital Humano.

Nesse sentido, conceber o trabalho em termos econômicos significa não analisá-lo tendo em vista a sua atribuição como mercadoria, nem mesmo compreendê-lo a partir da aferição do valor conferido à força de trabalho.

A apreensão do trabalho será realizada por meio da consideração de aspectos comportamentais e intelectuais do humano. A aferição do valor do trabalho se atrelará às aptidões e competências individuais, intangíveis, imateriais, isto é, ao "capital humano". 
A análise da Teoria do Capital Humano realizada pelos economistas consistiu, portanto, no exame do comportamento humano tendo em vista a influência das aptidões humanas na execução e no desempenho do trabalho e, consequentemente, no valor atribuído a ele.

Sob essa ótica, tendo como fundamento o aspecto econômico, promoveram-se análises acerca do trabalho e de seu valor econômico, não mais atribuído à força de trabalho em si, mas ao conjunto de capacidades humanas e de aspectos da personalidade que possibilitam sua realização e valorização.

Como desdobramento político e social da assunção dessa Teoria do Capital Humano e, consequentemente, da afirmação dos indivíduos como uma empresa, Foucault nos indicará que nos países desenvolvidos, a orientação de políticas econômicas, sociais, culturais e educacionais estará voltada para o investimento em capital humano. Nas palavras do autor:

A partir dessa análise teórica e dessa análise histórica, é possível destacar portanto os princípios de uma política de crescimento que já não será simplesmente indexada ao problema do investimento material do capital físico, de um lado, e do número de trabalhadores, [de outro], mas uma política de crescimento que será centrada muito precisamente numa das coisas que o Ocidente, justamente, pode modificar com maior facilidade e que vai ser a modificação do nível e da forma de investimento em capital humano. É para esse lado, de fato, que se vê claramente que se orientam as políticas econômicas, mas também as políticas sociais, mas também as políticas culturais, as políticas educacionais, de todos os países desenvolvidos. (FOUCAULT, 2008a, p. 319).

Dessa forma, a política de crescimento dos Estados não mais se concentrará exclusivamente na realização de investimentos voltados ao capital material, isto é, ao capital físico, uma vez que passará a envolver o investimento em políticas que levarão em consideração a dimensão imaterial do trabalho humano.

No que tange a tal dimensão, é importante que seja situada no contexto da evolução do capitalismo, de reestruturação produtiva, de transição de uma sociedade industrial para uma sociedade pós-industrial, na qual a economia do imaterial voltada para o acúmulo de ativos intangíveis gera como produto uma nova concepção de trabalho e de trabalhador, na medida em que altera substancialmente o relacionamento deste com aquele. Desse modo, vivencia-se a transição de um capitalismo industrial a um capitalismo cognitivo, no qual as dimensões intelectuais e do conhecimento assumem sua fundamentalidade para o trabalho, pois agregam valor ao trabalhador, permitindo-nos afirmar, na esteira de Sanson (2009, p. 71-72), que "O imaterial está ancorado no centro da nova economia."

Nesse processo de reestruturação produtiva que caracterizou o avanço do capitalismo, a substituição do trabalhador pelo maquinário atribuiu a ele novos domínios de atuação, novas funcionalidades, um novo valor. Tais compreensões são essenciais para a apreensão do que se denomina "capital humano", sobretudo porque esta encontra-se visceralmente relacionada à transformação epistemológica do "trabalho", compreendido como categoria cuja dimensão de análise econômica 
ensejou sua ressignificação. Os economistas neoliberais da Escola de Chicago atribuíram ao trabalho uma conceituação distinta daquela que o concebia como sinônimo de força bruta a ser exercida pelo trabalhador (COSTA, 2009, p. 175-176).

A partir do momento em que se passou a conceber o trabalho humano como uma conduta econômica, buscou-se atribuir o capital ao próprio indivíduo, isto é, ao próprio trabalhador. Sobre o tema, são esclarecedoras as palavras de Costa (2009, p. 177) ao afirmar que

[...] é esse mesmo indivíduo que se vê induzido, sob essa lógica, a tornar a si mesmo como um capital, a entreter consigo (e com os outros) uma relação na qual ele se reconhece (e aos outros) como uma microempresa; e, portanto, nessa condição, a ver-se como entidade que funciona sob o imperativo permanente de fazer investimentos em si mesmo - ou que retornem, a médio e/ou longo prazo, em seu benefício - e a produzir fluxos de renda, avaliando racionalmente as relações de custo/benefício que suas decisões implicam.

Essa descrição da lógica que passa a orientar o indivíduo no formato de uma empresa é corolário da generalização do modelo empresarial aplicado a toda a sociedade, à qual Foucault nos remete ao afirmar a existência de uma sociedade indexada pelo mercado, isto é, de uma sociedade na qual as ações governamentais são avaliadas conforme as leis do mercado. O laissez-faire que caracterizou o liberalismo clássico cede espaço a uma nova forma de regulação por meio da economia de mercado que consiste "[...] em não deixar o governo fazer, em nome da lei do mercado que permitirá aferir e avaliar cada uma de suas atividades." (FOUCAULT, 2008a, p. 339).

$\bigcirc$ que se percebe, portanto, é que o neoliberalismo norte-americano permite enxergar tanto o individuo quanto a sociedade e outros fenômenos não econômicos a partir das lentes do mercado, de modo a condicionar ações governamentais ao crivo da economia.

Tal assertiva nos serve de auxílio à compreensão da razão pela qual fenômenos como o trabalho humano, do qual tratamos anteriormente, e a justiça penal, que mencionaremos a seguir, sob a ótica dessa governamentalidade neoliberal estadunidense são compreendidos por meio de leituras mercadológicas condizentes com a racionalidade que as inspira.

O que Foucault apresenta em termos de neoliberalismo ao situá-lo no contexto norteamericano consiste na assunção do mercado como princípio de inteligibilidade que, diferentemente do que se sucedeu na Alemanha, assumirá, em sua aplicação, proporções capazes de alcançar questões atinentes às relações sociais e aos comportamentos individuais (RIBEIRO JUNIOR, 2013, p. 166-167) e que encontram no exemplo do programa de análise da criminalidade e da delinquência, formulado e desenvolvido nos Estados Unidos, mais uma expressão concreta de sua manifestação.

Sobre essa percepção da justiça penal a partir da ótica neoliberal, é importante que desde logo se observe que não será abordada por este artigo com profundidade, restringindo-se a tão somente mencioná-la para fins de uma breve apresentação capaz de introduzir a aplicação de seus fundamentos, o que, para esta proposta, cumprirá sua finalidade de contribuição teórica para 
a caracterização do que representou a racionalidade governamental neoliberal norte-americana na obra foucaultiana.

Dito isso, a começar pela concepção assumida do crime, parte-se de uma compreensão que, fundada no princípio de inteligibilidade do mercado, concebe o ato criminoso como uma conduta que implica riscos para o indivíduo agente que, por sua vez, consciente destes, dos rendimentos e das perdas que poderá obter como resultado, pratica a ação criminosa. Não se trata, portanto, de uma conduta criminosa concebida em termos de transgressão à lei passível de punição (FOUCAULT, 2008a, p. 339, 344-345).

É mais que isso. Os atos criminosos são condutas praticadas que envolvem diferentes riscos, sem que haja uma prévia valoração do que seja, do ponto de vista moral, mais ou menos lesivo à sociedade (FOUCAULT, 2008a, p. 356).

Em linhas bem gerais, afirma-se que no contexto da justiça penal, a preservação da liberdade de mercado se realizará por meio da legislação criminal e, especialmente, da política de moldura viabilizadora do intervencionismo jurídico, isto é, de uma intervenção no mercado por intermédio da lei (RIBEIRO JUNIOR, 2013, p. 169-170).

Valendo-se de um conjunto de instrumentos que atuam em paralelo com a legislação ("enforcement of law") para concretizar a lei na realidade social (FOUCAULT, 2008a, p. 347-348) o mercado do crime será regulado e a criminalidade controlada por meio da racionalidade da economia, preconizando em sua atuação a avaliação de custos e de benefícios da política a ser empregada (RIBEIRO JUNIOR, 2013, p. 172).

Em suma, o que se pretende enfatizar para fins de caracterização do neoliberalismo norteamericano consiste na abrangência de sua dimensão de aplicação, sobretudo quando comparada ao ordoliberalismo alemão, repercutindo em âmbitos que, a princípio, não manifestam seu relacionamento com a economia, a exemplo do trabalho e da criminalidade.

No decorrer das próximas sessões serão resgatados elementos essenciais da leitura de Foucault acerca da governamentalidade neoliberal, tendo como foco o problema central que orienta e movimenta todas as reflexões realizadas neste artigo, o qual implica oferecer respostas à seguinte questão: de que modo se concebe a racionalidade governamental neoliberal como potencialmente apta a operar na produção de relações de trabalho precárias e flexíveis a partir das Organizações Sociais de Saúde (OSSs)?

Tal direcionamento conduzirá a retomada da racionalidade governamental neoliberal no que concerne a questões como a aplicação do modelo empresarial na sociedade, isto é, a indexação da sociedade nos moldes do mercado e, mais que isso, remeterá a uma proposta de aplicação da Teoria do Capital Humano desenvolvida pelos neoliberais norte-americanos no contexto das OSSs, oferecendo importantes contributos ao problema de pesquisa. 


\section{Complexidades e tendências do mercado de trabalho em saúde e das relações laborais no setor a partir dos anos 1990}

A apreensão das complexidades que envolvem a questão do trabalho no âmbito da saúde é imprescindível para que se vislumbrem os impactos da restruturação produtiva e da nova ordem econômica global na organização e na produção dos serviços públicos de saúde no Brasil, a partir de um olhar sensível às relações peculiares que os envolvem, sobretudo por se tratar de um contexto de capitalismo periférico acentuador da desigualdade na relação capital-trabalho (MARTINS; MOLINARO, 2013).

Para tanto, convém situar as tendências do mercado de trabalho em saúde e das relações laborais que o compreendem no contexto do desenvolvimento do capitalismo e, especificamente, da alteração do regime produtivo industrial para o pós-industrial, ocorrida no Brasil a partir do final da década de 1980 e início da década de 1990, sobretudo por considerar tal modificação como um pressuposto para a compreensão das práticas precarizantes tanto em nível de gestão de recursos humanos em saúde, quanto sob a ótica das características das relações de trabalho que passam a constituir o setor.

No cenário internacional, a terceira revolução industrial, desencadeadora da emergência de uma nova ordem econômica, caracterizou-se pela restruturação produtiva, pela internacionalização do mercado e por uma revolução tecnológica. Na década de 1980, como consequência da transição de um modelo de produção fordista para um modelo social e econômico condizente com a realidade pós-industrial, vivenciase o desenvolvimento de novas relações de produção, sobretudo em razão da necessidade de ajustamento dos altos custos de produção da nova ordem (MARTINS; MOLINARO, 2013, p. 1668).

Nesse processo de transição, observa-se que o modo de produção, a concepção de trabalho, o perfil do trabalhador e a própria sociedade passam por uma profunda transformação. $\bigcirc$ modo de produção industrial, centrado na fábrica e no trabalho rígido, repetitivo, uniforme e padronizado da sociedade taylorista-fordista, cede lugar à flexibilidade e à fragmentação do processo produtivo. $\bigcirc$ modo de produção pós-industrial caracteriza-se por sua ênfase no setor de serviços e no trabalho imaterial, na desespecialização funcional e no trabalho multifuncional (ANTUNES; POCHMANN, p. 198-199).

No Brasil, de acordo com os apontamentos do economista José Celso Cardoso Júnior. (2006, p. 3, 10-11), pode-se afirmar que os reflexos dessas inovações relacionais na seara dos modos de produção foram resultados da transição de um modelo de desenvolvimento industrial, presidido pelo Estado, para uma estratégica de desenvolvimento orientada por reformas liberalizantes e internacionalistas, a exemplo da desestruturação e da desregulamentação do mercado de trabalho iniciadas nos anos 1980 e acentuadas nos anos 1990.

Ressalta-se que esses processos - de desestruturação e de desregulamentação do trabalho - são apresentados como decorrência de condicionamentos impostos pela macroeconomia e, especialmente, pelas políticas de cunho liberal adotadas pelo governo nacional. 
Nesse contexto, em seu estudo intitulado Macroeconomia e mercado de trabalho no Brasil: trajetória recente e tendência aparente, pautado em informações do Instituto Brasileiro de Geografia e Estatística (IBGE), Cardoso Júnior (2006, p. 11) sinaliza que, ao longo das duas últimas décadas, o processo de reestruturação do mercado de trabalho no Brasil foi caracterizado pelo crescimento do setor de comércio e de serviços, bem como da economia; pelo aumento de relações de trabalho informais; pelo aumento do nível de desocupação e de desemprego; pela precarização dos postos de trabalho; pela estagnação dos rendimentos médios do trabalho; pelo agravamento da distribuição funcional da renda e da distribuição pessoal dos rendimentos do trabalho; e pela mudança do modelo de mobilidade social intergeracional, em relação ao período compreendido entre as décadas de 1920 e 1980.

A importância de, preliminarmente, trazer essa percepção do mercado de trabalho nacional, nos anos 1980 e 1990, consiste em corroborar, especialmente em relação a esse período, o direcionamento da política macroeconômica para os interesses do mercado e a sua repercussão no mundo do trabalho mediante a flexibilização da regulação pública e, consequentemente, de direitos, a exemplo do redimensionamento estrutural do aparelho estatal perpetrado pela Reforma de Estado.

Concordamos com Martins e Molinaro (2013, p. 1669) quando afirmam que

[...] as demandas por flexibilização da regulação pública, geram demandas de flexibilização de direitos que se expressam em medidas legais que instituem: contratos por tempo parcial ou temporário, redução das contribuições sociais, diminuição da fiscalização sobre os contratos de trabalho, contrato de serviços de natureza de pessoa jurídica - "trabalhador como pessoa jurídica", medidas estas que resultam sempre em novas formas de contratação formal de trabalho sem proteção social.

Nesse sentido, as políticas desenvolvidas na década de 1990 também repercutiram diretamente na questão trabalhista, mediante a flexibilização da regulação pública vislumbrada nas alterações promovidas pela Emenda Constitucional n. 19/1998, ${ }^{5}$ afetando, inclusive, o mercado de trabalho da saúde.

A percepção de contratos fragilmente regulados na relação público-privada estabelecida entre a Admininstração Pública e as Organizações Sociais de Saúde (OSSs) tende a desencadear como consequência a execução e a legitimação tácita de práticas precarizantes no âmbito laboral que vão desde a "pejotização" à violência, a exemplo do assédio moral, sobretudo por se considerar que o contexto das profissões de saúde é permeado por relações complexas e de poder que potencializam a vulnerabilidade dos sujeitos envolvidos e que podem repercutir, inclusive, na assistência do serviço a ser prestado ao usuário (ASSUNÇÃO; JACKSON FILHO, 2011).

A fim de corroborar a afirmação de que a saúde pode ser vislumbrada como um campo sensível à projeção de violências no ambiente laboral, é importante mencionar o trabalho continuado

5 A Emenda n. 19/1998 modifica o regime e dispõe sobre princípio e normas da Administração Pública, Servidores e Agentes políticos, controle de despesas e finanças públicas e custeio de atividades a cargo do Distrito Federal, e dá outras providências. 
desenvolvido pelas pesquisadoras Elda Coelho de Azevedo Bussinguer e Sarah Hora Rocha intulado $O$ assédio moral laboral no setor da saúde (2014) e a pesquisa realizada por Sarah Hora Rocha, sob orientação de Elda Coelho de Azevedo Bussinguer, intitulada Violência e assédio moral em face dos exercentes da enfermagem: uma análise das relações de poder estabelecidas no ambiente laboral no setor saúde (2015).

A pesquisadora se propôs a investigar, a partir da percepção dos exercentes da enfermagem, o fenômeno da violência e do assédio moral sofridos em hospitais e serviços de saúde, tendo constatado, no discurso dos participantes da pesquisa, problemas diretamente relacionados às peculiaridades que envolvem a maioria das profissões de saúde, como as pressões sofridas no exercício da atividade laboral, o alto grau de exigências intelectuais, físicas e emocionais, a extensa e intensa carga de trabalho, os conflitos interprofissionais que ocorrem no relacionamento das equipes multidisciplinares de trabalho, etc. (ROCHA, 2015).

Tais questões, que impactam na vida e na saúde dos trabalhadores do setor saúde, devem ser analisadas tendo como pressuposto suas complexidades e, consequentemente, seu carácter multidimensional, isto é, devem ser correlacionadas a outros problemas que envolvem o campo e que podem potencializar a dimensão violenta que o envolve, a exemplo dos problemas relacionados à gestão de recursos humanos e à precarização do trabalho em hospitais, em unidades e em centros prestadores de serviços públicos de saúde administrados por OSSs.

Temos, nesse sentido, na flexibilidade de vínculos, na precarização do labor e na execução de serviços privatizados e, não raras vezes, também terceirizados, uma afetação excludente do trabalhador e, mais que isso, do trabalhador que se vê diante de um contexto, que a despeito de ser legitimado pela legalidade, o impõe o recurso à informalidade ou à precariedade do vínculo de trabalho como possibidade de subsistência.

Machado (2000a, p. 134) alerta quanto aos problemas que envolvem a política de recursos humanos em saúde, corroborados pela desarticulação da saúde como bem público daqueles responsáveis por produzi-la, isto é, dos trabalhadores. De acordo com a autora, diante de um contexto marcado por baixos salários, da precariedade de condições de trabalho para a execução das atividades essenciais, da ausência de incentivos e de infraestrutura adequada para o desenvolvimento de uma política de valorização profissional, dentre outras questões, os profissionais de saúde atuam na contracorrente da produção de uma saúde pública.

Ao tratar dos desafios postos ao setor de prestação de serviços de saúde Machado (2000a) reafirma a importância de se constituir uma agenda voltada para a formulação de políticas de recursos humanos, sobretudo por considerá-los um componente essencial na estrutura do Sistema Único de Saúde (SUS), tanto do ponto de vista da execução de uma técnica de gestão governamental, quanto sob a percepção do trabalhador de saúde como um bem público (MACHADO, 2000a, p. 145), sendo esta última uma questão que retomaremos adiante.

Dentre os grandes desafios do século XXI, propostos por Machado (2000a, p. 142-143), para a construção de uma agenda política de recursos humanos em saúde encontra-se a superação de 
alguns mitos, dentre os quais consideramos pertinente destacar o de que o setor privado é dispensável ao Sistema Único de Saúde (SUS). A autora considera o setor privado essencial ao setor público, sobretudo em razão de grande parte dos leitos hospitalares serem de propriedade privada. Nesse sentido, a atuação complementar desse subsetor do Sistema Único de Saúde (SUS), financiada por fontes públicas, impõe como necessidade a consideração de que a política de recursos humanos para esse setor de serviços não pode ser formulada sem que haja diálogo com o privado.

Tal ponto merece nossa atenção em razão da importância de esclarecer que a crítica dirigida à gestão privada realizada por OSSs e a sua potencial tendência a práticas e políticas precarizadoras de vínculos laborais não pretendem negar a influência e a importância do setor privado para a produção de serviços de saúde. Pelo contrário, partindo do pressuposto de sua relevância, contesta-se justamente a necessidade de uma firme regulação sobre o trabalho daqueles responsáveis por produzir saúde, a fim de que sejam asseguradas condições adequadas ao alcance de uma assistência de qualidade.

No entanto, não se pode perder de vista o relacionamento entre a prestação de serviços públicos por entes privados e a desarticulação da percepção dos trabalhadores de saúde como bens públicos.

Sobre a apreensão do trabalhador de saúde como um bem público, afirma-se que consiste em uma concepção sensível da gestão dos recursos humanos que atribui ao trabalhador uma função não utilitária, não instrumental. O trabalhador não é um objeto, é, como mencionado anteriormente, um elemento imprescindível para o funcionamento do Sistema Único de Saúde (SUS). Na esteira dos ensinamentos de Machado (2009),

[...] o trabalhador é percebido como sujeito e agente transformador de seu ambiente e não apenas um "recurso humano" realizador de tarefas previamente estabelecidas pela administração local. Nessa abordagem, o trabalho é visto como um processo de trocas, de criatividade, co-participação, e co-responsabilização, de enriquecimento e comprometimento mútuos.

Tal afirmação implica o reconhecimento de políticas de recursos humanos como integrantes inafastáveis da agenda política, de uma política de Estado, e não apenas como de uma ação do governo, concepção que já havia sido proposta desde o movimento da Reforma Sanitária, mas que como consequência das reformas liberalizantes, realizadas no Brasil na década 1990, sofreu uma significativa mitigação.

Entre as tendências do mercado de trabalho em saúde no Brasil, a flexibilidade, a precarização de vínculos, a acentuação do desemprego e o aumento da informalidade podem ser apontados como dados alarmantes diretamente relacionados à onda de reformas neoliberais fomentadas na década de 1990 (KALLEBERG, 2009; MACHADO; OLIVEIRA; MOYSES, 2011, p. 9), o que pode ser compreendido como resultado de uma racionalidade governamental orientada pelo dinamismo do mercado. 
Ressalta-se que, no que tange à gestão dos recursos humanos, a década de 1990 foi reconhecida como um período no qual se caminhou na contramão do que a Reforma Sanitária preconizou. As reformas neoliberais, ao priorizarem a privatização mediante terceirização de serviços e ao flexibilizarem as relações de trabalho, fizeram com que os trabalhadores deixassem de ser vislumbrados como um elemento constitutivo para a consolidação do Sistema Único de Saúde, ou seja, deixassem de ser percebidos como bens públicos (MACHADO, 2009).

Corroborando o quadro de influência do neoliberalismo no campo da saúde, Rizzoto (2009) apresenta as consequências das reformas realizadas na estrutura administrativa em todo o País de modo sucinto e enfático, destacando, entre outras questões, a mercantilização dos serviços de nível secundário e terciário, tendo registrado que cerca de $70 \%$ da oferta se situa no setor privado, na precarização dos vínculos de trabalho no setor público e na terceirização de serviços assistenciais e terapêuticos.

Nesse contexto, a compreensão do trabalhador de saúde como um bem público, fundamental ao setor, tem como pressuposto a garantia de condições de trabalho decente ${ }^{6}$ e, nessa perspectiva, considerando a conjuntura jurídico-política que legitimou a estratégia de transferência de gestão ao âmbito privado, afirma-se que seu impacto na formulação e no acompanhamento de políticas de gestão de recursos humanos no interior das OSSs foi coerente aos fundamentos inspiradores da reforma administrativa dos anos 1990, repercutindo diretamente na estabilidade das relações empregatícias, na (in)segurança jurídica do trabalhador de saúde e, consequentemente, na mudança da percepção desse sujeito que, ao ter sua esfera jurídica contratual afetada pela flexibilidade de contratos fragilmente regulados, deixa de ser percebido como bem público e passa por um processo de estranhamento em relação aos serviços que produz, afetando, para além da esfera jurídica, sua própria dignidade.

O que se preconiza com o reconhecimento do trabalhador da saúde como bem público é afirmá-lo como um elemento constitutivo fundamental ao complexo de serviços de saúde a serem prestados também porque à medida que se assegura a esses trabalhadores um status de cidadania capaz de conscientizá-lo, contribui-se, de modo correlato, para que a relação profissional de saúdeusuário seja virtuosa, uma vez que "[...] a produtividade e a qualidade dos serviços oferecidos à sociedade serão, em boa parte, reflexos da forma e das condições com que são tratados os que atuam profissionalmente na organização." (ARIAS et al., 2006, p. 119).

Daí dizer-se, corroborando o entendimento de Machado (2009), que a gestão do trabalho em saúde deve ser compreendida, analisada e considerada como um dos eixos estratégicos de trabalho do Sistema único de Saúde (SUS), sob pena de comprometermos todo o fundamento sobre o qual se

\footnotetext{
6 De acordo com a definição da Organização Internacional do Trabalho, por trabalho decente entende-se aquele que, encontrando convergência nos quatro objetivos da Organização Internacional do Trabalho (OIT), assegura "[...] o respeito aos direitos no trabalho (em especial aqueles definidos como fundamentais pela Declaração Relativa aos Direitos e Princípios Fundamentais no Trabalho e seu seguimento adotada em 1998: (i) liberdade sindical e reconhecimento efetivo do direito de negociação coletiva; (ii)eliminação de todas as formas de trabalho forçado; (iii) abolição efetiva do trabalho infantil; (iv) eliminação de todas as formas de discriminação em matéria de emprego e ocupação), a promoção do emprego produtivo e de qualidade, a extensão da proteção social e o fortalecimento do diálogo social." (ORGANIZAÇÃO INTERNACIONAL DO TRABALHO, 2017).
} 
sustenta o sistema e até mesmo impedir que a humanização do atendimento ao usuário se estabeleça de modo efetivo.

\section{Relações entre o público e o privado no âmbito laboral: o (des) valor do trabalho humano na governamentalidade neoliberal}

A apresentação do cenário de (des)valor do trabalho humano na governamentalidade neoliberal tem como premissa fundamental a identificação de relações de interesse que perpassam o público e o privado, interferindo na percepção que se tem acerca do que se configura como trabalho digno e decente e, consequentemente, no que se considera como exploração do trabalhador.

Portanto, a demarcação do que se entende por relações de interesse é essencial para este artigo na medida em que se tem em vista o fato de que tais relações tornam fluidas as fronteiras da dignidade no trabalho, ou seja, têm o condão de dignificar ou, em contrapartida, de naturalizar o aviltamento, a depender do interesse público ou privado assumido como fundamento analítico.

Nesse ponto, manifesta-se conformidade às considerações de Sarmento (2007, p. 29-30) ao afirmar que "[...] as fronteiras entre o público e o privado são extremamente móveis e instáveis, e que a prioridade atribuída a cada um dos elementos do par também oscila ao sabor das mutações políticas e cosmovisivas."

Reforçando o caráter móvel e instável que integra a atribuição do interesse público e do privado, alude-se ao conceito de res publica em resgate à dimensão filosófica do que se caracteriza como interesse público, mas também para pontuar que tal fundamento - o de res publica - foi suscitado por Bresser-Pereira (2001) como justificativa do interesse despertado pela Reforma do Estado, sobretudo em razão de se buscar proteger a coisa pública ante as tendências privatizantes. Valendo-se de uma fundamentação, em tese, condizente com tais fins, de acordo com o autor:

O Estado deve ser público, as organizações públicas não-estatais, sem fins lucrativos devem ser públicas. Bens estritamente públicos, como o meio ambiente, devem ser públicos e como tal protegidos. Direitos públicos são os direitos que nos asseguram que a coisa pública, a res publica, entendida em sentido amplo para incluir a carga tributária, seja pública - que seja de, e para todos, em vez de ser objeto de rent-seeking, de ser privatizada por grupos de interesse. (BRESSERPEREIRA, 2001, p. 8).

Sob essa cosmovisão tender-se-ia a considerar organizações públicas não estatais, das quais as Organizações Sociais de Saúde (OSSs) são um exemplo, como bens eminentemente públicos, a despeito de sua configuração jurídica de entidade privada sem fins lucrativos.

Em dissonância com tal assertiva, considera-se que a definição do que caracteriza a natureza pública ou privada de um organismo é fundamentalmente o interesse que o funda e que norteia suas 
ações. Nesse sentido, OSSs, a despeito de serem comumente reconhecidas como o "público não estatal", podem possuir natureza privada e serem movidas por tais fins.

Entidades públicas sem fins lucrativos, como as OSSs, também visam a capitais que não necessariamente o financeiro. $\bigcirc$ poder atribuído à gestão de tais entidades, por si só, é objeto de desejo, induzindo-se a refletir acerca desse ente privado que leva nome e vantagens de público, mas que, a despeito da destinação não lucrativa, pode produzir outros capitais sem lucrar pelo dinheiro, mas pelo poder de gerir, de administrar recursos humanos e de, assim, agir de modo condizente aos interesses da racionalidade governamental que os fomenta.

Considera-se haver, sim, uma relação de interesse público, de cunho administrativo, que se expressa entre o poder público e o ente privado representado pelas OSSs, caracterizada pela contratualização firmada para o exercício da gestão. É o ente público que qualifica a Organização Social de Saúde e que efetivamente contrata o ente privado.

No entanto, no bojo dessa mesma relação entre o ente público e o privado, há interesses privados, há interesses particulares, há relações de interesses capazes, inclusive, de justificar a orientação das políticas governamentais. No entanto, essa percepção não consiste em tarefa simples. Pelo contrário, guarda complexidades que, por vezes, levam a considerar, conforme propõe Bahia (2010, p. 120), a necessidade de

[...] apreender o uso corrente das noções de público e privado e incorporar a existência do privado (inclusive assistencial) no SUS e do público (inclusive assistencial) no privado e buscar ampliar as fronteiras de aplicação desse par conceitual para aprimorar o conhecimento sobre a gênese e dinâmica das políticas de saúde contemporâneas.

Como demonstração dessa relação de interpenetração entre os atores públicos e privados no processo da política pública de saúde, convém mencionar a pesquisa coordenada pelos professores Ligia Bahia e Mario Scheffer (2015) acerca do financiamento de campanha política por parte das empresas de assistência suplementar. Os dados obtidos no referido estudo, ${ }^{7}$ disponibilizado pelos referidos professores, revelam as relações nefastas entre privado e público capazes de justificar a orientação das políticas governamentais.

De modo objetivo e direto, ao dimensionar a abrangência das relações entre o público e o privado, a pesquisadora Bahia (2010, p. 118) esclarece que "O público e o privado designam distintas situações de grupos sociais mais complexos e referem-se, respectivamente, àquilo que pertence ao coletivo, à comunidade e a membros singulares de uma dada sociedade."

\footnotetext{
7 A pesquisa foi realizada pela primeira vez no ano 2002 e desde então vem sendo atualizada. Os dados apresentados neste estudo referem-se à atualização realizada no ano 2015, com base nos dados obtidos nas eleições de 2014.
} 
No entanto, a autora sugere que o desafio que consiste em categorizar o que se apresenta como público e como privado não se exauri nessas definições simplistas, principalmente quando se direciona a análise para o cotidiano da saúde (BAHIA, 2010, p. 118).

No contexto das instituições públicas e privadas de saúde, a falta de clareza quanto ao que se define como "público" e como "privado" é reforçada, tanto pelas interações complexas entre o público e o privado no âmbito da saúde, quanto pela sugestiva incorporação, a partir da década de 1990, de novos vocábulos cujo teor técnico-gerencial apenas corroboram a difícil clivagem entre esses conceitos aparentemente antagônicos. Nesse sentido,

A complexificação das relações entre o público e o privado no setor saúde no Brasil e, sobreudo, a adoção especialmente a partir da segunda década dos anos 1990, e uma gramática e um vocabulário técnico-gerencial, não mais marcado pelas oposições clássicas entre público e privado ou estatal e privado, mas pela 'convicção' sobre a virtuosa relação entre Estado e mercado, trouxe consido novas conotações para o público e para o privado. (BAHIA, 2010, p. 119).

Feitas essas pontuações e ressalvada a complexidade conceitual, importa dimensionar na conjuntura dessa inter-relação público-privada os impactos no direito fundamental ao trabalho e à saúde, os quais se encontram diretamente relacionados ao objeto de estudo deste artigo por tratarem diretamente da fragilização de direitos trabalhistas em entidades privadas gestoras de recursos públicos e prestadoras de serviços de saúde cujo interesse público é corroborado, por exemplo, por ser a assistência médica e hospitalar comumente gerida por OSSs e, além disso, um serviço considerado essencial (inciso II, do art. 10, da Lei n. 7.783/1989).

Cumpre enfatizar preliminarmente a relevância de se assegurar o trabalho como Direito Humano Fundamental. Considerando que o trabalho é um direito social, pertinente compreender a importância de se conceber Direitos Sociais como Direitos Fundamentais. O primeiro marco internacional relevante para o avanço das reflexões propostas visando ao esclarecimento da adoção terminológica da expressão "Direitos Fundamentais Sociais" é a Declaração Universal dos Direitos Humanos, de 1948, da Organização das Nações Unidas (ONU), diploma responsável por reconhecer os Direitos Sociais, juntamente aos Civis e Políticos, como Direitos Humanos, e, portanto, universais e indivisíveis. $\bigcirc$ art. 25 desse instrumento normativo reconhece a saúde e o bem-estar como Direitos Humanos. Outro diploma internacional que merece destaque é o Pacto Internacional de Direitos Econômicos, Sociais e Culturais (PIDESC), de 1976, o qual foi responsável pelo estabelecimento de diretrizes e obrigações para a implementação da proteção e do bem-estar social . $\bigcirc$ art. 12 desse pacto reconhece o direito a gozar do "[...] melhor estado de saúde física e mental possível de atingir." (ORGANIZAÇÃO DAS NAÇÕES UNIDAS, 1976).

No Brasil, embora desde 1934 já fosse possível verificar a previsão de direitos sociais nas Constituições, a exemplo do art. 121, $₫ 1^{\circ}$, alínea "h", que previa o direito à assistência médica e sanitária ao trabalhador (BRASIL, 1934), foi apenas com a Constituição da República de 1988 que o rol de Direitos 
Sociais foi ampliado, enunciando, inclusive, programas a serem perseguidos pelo Estado e pela Sociedade (arts. 196, 205, 217) e, mais que isso, integrando tais direitos ao elenco dos Direitos fundamentais, reforçando a indivisibilidade dos Direitos Humanos (PIOVESAN; VIEIRA, 2006, p. 131).

A Constituição de 1988 representou a transição paradigmática de um Estado Social, focalizado no Executivo, para um Estado Democrático de Direito, socialmente comprometido em viabilizar a participação popular, inaugurando uma ordem jurídica constitucional que, para além da mera positivação de direitos, ocupou-se de instrumentalizá-los visando a sua concreta implementação, sob pena de ferir a própria democracia (PIOVESAN; VIEIRA, 2006, p. 131, 133).

Além disso, ao consagrar a Dignidade Humana como princípio fundamental, norteador do constitucionalismo brasileiro, a referida Carta Constitucional prestigiou a universalidade dos Direitos Humanos, tendo, inclusive, incluído, a partir da Emenda Constitucional n. 45, tais direitos no rol dos direitos fundamentais assegurados constitucionalmente (PIOVESAN, VIEIRA, 2006, p. 131).

Ressalta-se, portanto, que a consagração dos Direitos Sociais como Direitos Humanos Fundamentais decorre do reconhecimento desses direitos, no plano internacional, assegurando a universalidade e a indivisibilidade e, num segundo momento, da incorporação dos Direitos Sociais no plano interno da Constituição dos países. Nessa perspectiva, "Os direitos fundamentais seriam esses mesmos Direitos Humanos consagrados na Carta da ONU, em tratados, em convenções e no direito internacional, mas positivados nas constituições da maioria dos Estados-nacionaismembros das Nações Unidas." (KROHLING, 2009, p. 44).

Daí decorre a afirmação de que o direito ao trabalho, reconhecido por instrumentos normativos nacional e internacionalmente, ${ }^{8}$ é um Direito Social, Humano e Fundamental, argumento relevante para elidir interpretações que visem sustentar a não obrigatoriedade e a não autoaplicabilidade desses direitos, bem como a não inclusão destes na cláusula de abertura do art. $5^{\circ}$, $\int 2^{\circ}$, da Constituição Federal.

Para além dessa definição jurídica, importa reconhecer, na esteira do que sugere Wandelli (2016), que o direito humano fundamental ao trabalho possui um conteúdo próprio, de nítido contorno, que impõe a observância de deveres e de prerrogativas jurídicas, paralelamente ao seu amplo caráter protetivo, que deve, inclusive, ser vindicado como direito: o direito ao conteúdo do próprio trabalho, o qual determina juridicamente as condições da atividade e da organização do trabalho, em consonância com o conteúdo recentemente proposto pelo Alto Comissariado em Direitos Humanos da Organização das Nações Unidas.

Nesse sentido, o conteúdo do direito ao trabalho comporta mais do que assegurar o trabalho e sua executividade. Implica proporcionar de modo qualitativo (e não apenas formal) a ocupação de

\footnotetext{
8 Art. 23 da Declaração Universal dos Direitos Humanos (DUDH) de 1948; Arts. $6^{\circ}, 7^{\circ}$ e $8^{\circ}$ do Pacto Internacional de Direitos Econômicos, Sociais e Culturais (PIDESC); Art. $6^{\circ}$ do Protocolo de São Salvador; Art. 45, b, da Carta da Organização dos Estados Americanos; A afirmação de que o trabalho não é objeto de mercancia ocorreu em 1919 quando da criação da Organização Internacional do Trabalho (OIT); dentre outros diplomas normativos internacionais.
} 
postos de trabalho que permitam o desenvolvimento das capacidades e habilidades humanas tendo em vista a autorrealização e o bem comum (WANDELLI, 2016, p. 1029-1030).

Esclarecidas tais premissas acerca da repercussão jurídica da consagração do trabalho como um direito humano, retornaremos a problematização proposta.

Considera-se que a reforma do Estado, ocorrida nos anos 1990, contribuiu para o agravamento de crises, no âmbito laboral e da saúde, diretamente ligadas ao modo como o público e o privado passaram a se relacionar, conduzindo a questionamentos quanto às compreensões de "trabalho humano" e de "saúde" no contexto da Governamentalidade neoliberal, levando em consideração a correlação dessas perspectivas com a precarização do trabalho nas Organizações Sociais de Saúde (OSSs).

Isso implica afirmar que o trabalho e a saúde, concebidos a partir da racionalidade governamental neoliberal, passam a assumir conotações correlatas ao modelo de sociedade empresarial aduzido por Foucault e, consequentemente, passam a figurar como objetos postos à disposição no mercado e, portanto, passíveis de comercialização.

Sob essa ótica, o trabalho passa a absorver dimensões precarizantes, na medida em que se coaduna com a assimilação e com a legitimação da fragilidade dos vínculos mediante a adoção de medidas como as contratualizações fragilmente reguladas e pouco protetivas dispensadas ao trabalhador, este último assimilado como um recurso humano, isto é, como um indivíduo capitalizado, cujo valor se afirma justamente pelo embricamento capital-trabalhador, como articulado na teoria do capital humano.

Do mesmo modo, a saúde passa a ser compreendida como uma mercadoria, como um bem de consumo à disposição daquele que possuir recursos financeiros suficientes para adquirila, convertendo-se em "[...] um benefício adquirido mediante pagamento prévio", comprometendo substancialmente sua dimensão de direito de cidadania assegurado universalmente (FLEURY; OUVERNEY, 2008, p. 1, 12-13; ESCOREL; TEIXEIRA, 2012, p. 279-322), tornando explícito o caráter excludente e discriminatório do conceito descrito, uma vez que vincula os "benefícios" de saúde oferecidos à capacidade contributiva dos usuários.

Nesse sentido, imprescindível reconhecer que ao conceber a saúde como objeto de consumo, isto é, como mercadoria disponível àqueles que possuem condições de adquiri-la, ressaltamos, sob uma perspectiva perversa, um conceito de saúde que não se coaduna com sua dimensão de cidadania e emancipação, entendimento corroborado por Garrafa (2003, p. 52) ao afirmar que:

No mundo globalizado do século XXI, com raras exceções, a saúde passou a ser mais um objeto de consumo no supermercado capitalista de ofertas: quem tem recursos compra boa mercadoria (diálises renais, transplantes, medicamentos de última geração), quem não tem sucumbe. Em um processo crescentemente perverso de compra e venda, a saúde deixou de ser um instrumento de cidadania e libertação de pessoas e povos. 
Ressalta-se que a afirmação da saúde como um bem de consumo propicia desdobramentos que merecem ser destacados por também guardarem íntima relação com os objetivos desta pesquisa, uma vez que como corolário de sua afirmação se tem a configuração do usuário dos serviços de saúde como um cliente e não como o usufrutuário de um direito de cidadania, e o trabalhador ("recurso humano"), prestador de tais serviços, em conformidade com esse enquadramento do usuário, tende a incorporar em suas práticas a lógica que o mercado lhe instiga: produtividade, celeridade, percepção de custos e benefícios, lei da oferta e da procura, etc.

Sob essa ótica, a ética do cuidado, da humanização e da alteridade na relação com o usuário restam comprometidas, e a gestão do trabalho em saúde, por sua vez, deixa de ser assumida como um eixo estratégico de trabalho do Sistema Único de Saúde (SUS), na medida em que tanto a saúde quanto os trabalhadores que nela atuam deixam de ser assumidos como um bem público (MACHADO, 2009).

A lógica empresarial que passa a integrar tais concepções é reproduzida nas relações que se estabelecem socialmente e, direcionando para o foco analítico deste artigo, repercute nas OSSs, tanto por meio das relações trabalhistas que são estabelecidas em seu interior, quanto pelo fato de tais relações assumirem maior grau de vulneração por sua natureza de prestação de um serviço público essencial e de um direito fundamental.

Corroborando a incidência racional e macropolítica dessa lógica empresarial, ao discorrerem acerca de uma nova razão de mundo, de matriz eminentemente neoliberal, que se desenvolve no mundo ao longo do século XX, Dardot e Laval (2016) sugerem a proeminência de uma nova racionalidade cuja centralidade se encontra justamente no empresariamento do sujeito e das relações, tal qual sustenta Foucault ao tratar do ajustamento da sociedade nos moldes de empresa, condicionando as relações sociais à observância de um sistema normativo pautado no gerencialismo capitalista. Nesse contexto, propício à emergência da "era pós-democrática", a dimensão pública e democrática dos Estados Nacionais sucumbe a serviço de uma lógica individualista, consumista e, consequentemente, desprotetiva no que concerne aos direitos sociais.

Sendo o direito ao trabalho um direito social e, mais que isso, um direito humano fundamental cujo valor - o valor social do trabalho - constitui a dignidade humana ao mesmo tempo em que é desdobramento da cidadania (LEITE, 2011, p. 93-98), sua desvalorização por quaisquer empreendimentos deve ser elidida e combatida.

Tal assertiva é corroborada pela percepção de Santos (2003, p. 19) ao considerar que:

Ao perder o estatuto político que detinha enquanto produto e produtor de cidadania, o trabalho fica reduzido a dor da existência, quer quando há - sob a forma de trabalho desgastante -, quer quando não há - sob a forma de desemprego, e não menos desgastante. É por isso que o trabalho, apesar de dominar cada vez mais as vidas das pessoas, está a desaparecer das referências éticas que dão suporte à autonomia e à auto-estima dos sujeitos. 
Essa é a razão pela qual a precariedade nas relações laborais ainda hoje se constitui como pauta de reivindicações de movimentos sociais que buscam impedir a naturalização de práticas que, embora legalmente amparadas, sejam desprotetivas, e também as que, a despeito de serem ilegais, são reiteradas no cotidiano do obreiro.

Ao descrever o mundo do trabalho no contexto do que nominaram como "era da mundialização do capital", Antunes e Alves (2004, p. 343) caracterizam a classe trabalhadora no século XXI como ainda mais fragmentada, mais heterogênea e mais diversificada, uma sociedade que é também marcada por "[...] uma perda significativa de direitos e de sentidos, em sintonia com o caráter destrutivo do capital vigente."

Esse cenário no qual o trabalho se situa é propício a sua precarização multiforme, dos subempregos ao desemprego e deste a informalidade, reforçando a permanência da centralidade da categoria trabalho no mundo contemporâneo (ANTUNES; ALVES, 2004).

O que se constata é um agravamento da exploração do trabalhador a níveis alarmantes no contexto das transformações identificadas no perfil do trabalho e do trabalhador deste século comparativamente àquele do século antecedente.

Acerca de tais mutações ocorridas no mundo do trabalho, Antunes e Alves (2004, p. 336342) são enfáticos ao elencarem o que para eles são consideradas as principais tendências desse processo:

a) a substituição do proletariado fabril estável das indústrias taylorista e fordista por modalidades desregulamentadas de trabalho, como decorrência da reestruturação produtiva do capital;

b) o aumento no número de trabalhadores terceirizados, subcontratados, temporários, informalizados, etc. nas fábricas e no setor de serviços;

c) o crescimento de mulheres exercentes de atividades laborais por vezes precárias e desregulamentadas que, a despeito de representarem em alguns países uma força de trabalho numericamente superior à dos homens, possuem uma média salarial inferior, além de direitos sociais tutelados de modo desigual;

d) aumento de assalariados de nível médio no ramo destinado aos serviços, como produto direto do neoliberalismo e de suas políticas;

e) o caráter excludente do capital em relação a trabalhadores jovens, os quais, diante da possibilidade do desemprego, não raras vezes, submetem-se a trabalhos precários;

f) o caráter excludente do capital em relação a trabalhadores idosos que veem na informalidade um recurso útil para sua subsistência, sob pena de se sujeitar ao desemprego;

g) a incorporação de trabalhadores, mesmo que de forma precária, por parte do terceiro setor; 
h) o aumento do trabalho realizado em domicílio, inaugurando modalidades de flexibilização e de precarização do labor por meio de recursos telemáticos e agravando a exploração em relação às trabalhadoras mulheres que se veem diante de uma aglutinação de atividades ao universo do trabalho doméstico;

i) o caráter transnacional alcançado pelo contexto laboral, sobretudo em razão da internacionalização do próprio capital.

Nesse universo diversificado e disforme que passa a caracterizar o universo do trabalho há um contingente de trabalhadores submetidos a processos de informalização e de precarização. A expansão das formas de trabalho precário "[...] vêm ampliando as formas geradoras do valor, ainda que sob a aparência do não valor, utilizando-se de novos e velhos mecanismos de intensificação (quando não de autoexploração do trabalho." (ANTUNES, 2011, p. 407).

Há, portanto, uma espécie de valorização às avessas que se manifesta no caráter destrutivo da descartabilidade do trabalhador, uma vez que à medida que este se torna supérfluo, sua força de trabalho se torna mais frágil e suscetível à autoexploração.

Trata-se, portanto, de uma destrutividade que se expressa intensamente quando descarta, tornando ainda mais supérflua, parcela significativa da força mundial de trabalho, onde milhões encontram-se realizando trabalhos parciais, precarizados, na informalidade ou desempregados. Isso porque na eliminação/utilização dos resíduos da produção, o capital desemprega cada vez mais trabalho estável, substituindo-os por trabalhos precarizados, que se encontram em enorme expansão no mundo agrário, industrial e de serviços, bem como nas múltiplas interconexões existentes entre eles, como na agroindústria, nos serviços industriais ou na indústria de serviços. A eclosão generalizada do desemprego estrutural em escala transnacional é a expressão-limite mais aguda e trágica dessa destrutividade presente no mundo do trabalho. (ANTUNES, 2011, p. 408).

Ainda sobre esse contexto de expansão do trabalho precário no mundo, ao dissertar sobre os modos de ser da informalidade, Antunes (2011) apresenta uma caracterização dessa informalidade a partir das seguintes modalidades: os trabalhadores informais tradicionais, que podem ser "ocasionais" ou "temporários"; os trabalhadores informais assalariados sem registro; e os trabalhadores informais por contratação própria.

A análise desse quadro de informais, situado como decorrência direta de uma sociedade globalizada na qual a "precarização estrutural do trabalho" se apresenta como uma tendência em potencial expansão, somada à flexibilização legislativa, corrobora o desmonte dos direitos sociais que se dirigem à classe trabalhista. Nas palavras de Antunes (2011, p. 411),

É nesse quadro, caracterizado por um processo tendencial de precarização estrutural do trabalho, em amplitude ainda maior, que os capitais globais estão exigindo também o desmonte da legislação social protetora do trabalho. E flexibilizar essa legislação social significa - não é possível ter nenhuma ilusão sobre isso - aumentar ainda mais os mecanismos de extração do sobretrabalho, ampliar 
as formas de precarização e destruição dos direitos sociais que foram arduamente conquistados pela classe trabalhadora, desde o início da Revolução Industrial, na Inglaterra, e especialmente pós-1930, quando se toma o exemplo brasileiro.

Sobre os impactos desses capitais globais nos direitos sociais, destaca-se a mercadorização do trabalho humano sob os auspícios de entidades internacionais que sustentam, sob a escusa de empréstimos que visam ao incentivo do desenvolvimento de políticas sociais a determinadas nações, a imposição de medidas que comprometem significativamente o avanço e o implemento de tais políticas.

Nessa perspectiva, há que se confrontar a influência exercida por entidades internacionais na política interna de países politicamente dependentes, isto é, de países caracterizados pela potencialidade mercantil e pelo inexpressivo desenvolvimento no campo das políticas de bem-estar social, nos quais a frágil consolidação de direitos civis e políticos contribui para a adesão de medidas de flexibilização das fronteiras nacionais e das políticas, sujeitando-as às ingerências de organizações que, por exercerem significativo domínio sob o capital estrangeiro, detêm o controle das influências nos investimentos transnacionais.

Em suma, considera-se que o (des)valor do trabalho humano na governamentalidade neoliberal se manifesta na desigualdade estrutural, como desdobramento de uma ordem global cujos impactos se dimensionam em prejuízo do trabalhador, produzindo relações caracterizadas por seu caráter flexível e desregulamentado.

No entanto, entende-se, na esteira de Souto Maior (2002), que o discurso que se restringe a atribuir à globalização e à informatização a motivação para o agravamento do quadro de desvalor do trabalho e do trabalhador não deve ser absorvido sem ressalvas, sob pena de esgotamento da afirmação da injustiça social, da desigualdade e da exclusão nos argumentos da "modernidade" e do "fatalismo", como se não houvesse alternativa ao pensamento e à história, isto é, como se só fosse possível pensar tais problemáticas como "decorrência natural e inevitável da globalização."

A flexibilização trabalhista consiste em uma "[...] adaptação das regras jurídicas a uma nova realidade, gerando um novo tipo de regulamentação" (SOUTO MAIOR, 2002), e vem sendo empregada no contexto de uma racionalidade governamental que se funda no neoliberalismo, como forma de desestabilização das relações trabalhistas, isto é, como forma de assegurar situações instáveis, inseguras, em afirmação da prevalência do capital sobre a força de trabalho.

Complementarmente, a desregulamentação trabalhista é definida pela "[...] ideia de eliminação de normas do ordenamento jurídico estatal que não mais se justificariam no contexto social, incentivando-se a autorregulação pelos particulares." (SOUTO MAIOR, 2002).

Tanto a flexibilização quanto a desregulamentação são instrumentos apontados por Souto Maior (2002) como produtos da consciência econômica do direito do trabalho, que visam reduzir os custos do trabalho com vistas a satisfazer o interesse econômico.

Sob a ótica da governamentalidade neoliberal, os efeitos da articulação de tais instrumentos podem ser percebidos pela constatação de uma sociedade indexada na forma da empresa que 
reproduz nas relações laborais que se desenvolvem em sua conjuntura a mesma lógica concorrencial que a orienta. Nesse sentido, tomando por base a descrição de Souto Maior (2002) do que viria a caracterizar uma sociedade na qual a consciência econômica se sobrepõe à consciência social e, assim, produz e fomenta injustiças, observamos que

[...] a sociedade que deveria se basear pelo pacto de solidariedade, se caracteriza, então, pela luta de todos contra todos, pelo salve-se quem puder: e que vença o melhor mais competente. Os custos de formação profissional preparam o jovem para este mundo da competição, e seja o que Deus quiser!

Como corolário da indexação da sociedade nos moldes da empresa, sugerimos que a governamentalidade neoliberal se estabelecerá no fomento cotidiano a essa lógica competitiva e desigual no seio da sociedade e no âmbito do trabalho.

Todavia, o grande paradoxo dessa sociedade caracterizada pela influência de valores inspirados pelo liberalismo econômico consiste justamente no fato de ter como fundamento jurídico e coercitivo o mesmo direito do trabalho tradicional que se constituiu durando a vigência do que foi reconhecido como o "Estado Social" e que é manifestamente oposto ao direito do trabalho (re) produzido pela ordem mercadológica.

Nas palavras de Souto Maior (2002): "Sob o ponto de vista exclusivo das relações de trabalho, o direito do trabalho tradicional constituiu-se óbice à consagração do 'novo' modo de ordenação do mercado, cada vez mais à busca da lógica da lei da oferta e da procura."

Conforme sugere o autor, é por essa razão que o alicerce do direito do trabalho vem sendo alterado como estratégia de conformação ao padrão liberal de relacionamento trabalhista. Desse modo,

A ideia de flexibilização, de mero ideal econômico, passa, então, a integrar a base do direito do trabalho que passa a ser visto como um instrumento não da construção da justiça social, mas como ponto de equilíbrio das forças entre empregado e empregador, um equilíbrio, no entanto, que se amolda facilmente às possibilidades econômicas e à completa ausência de força dos trabalhadores para resistirem aos avanços econômicos sobre os seus direitos, em razão do desemprego, o que implica, até mesmo, uma mudança na denominação do direito do trabalho, que começa a ser visto como 'direito ao trabalho', não importando qual trabalho. (SOUTO MAIOR, 2002).

Vemos se constituir um alicerce sobre o direito do trabalho orientado por fundamentos provenientes da lógica do mercado, viabilizando a legitimação da precariedade laboral na forma de práticas lesivas ao trabalhador, dentre as quais se situa a alteração da legislação trabalhista.

A precariedade das relações laborais torna o trabalhador suscetível à ilegalidade dos subempregos, das subcontratações, da submissão irrestrita ao poder diretivo do empregador, do assédio moral ao físico, etc. 
É nesse contexto de desconstrução do trabalho ante uma ordem econômica inexorável, marcada por profundos retrocessos em termos sociais, que buscamos confrontar ao sugerirmos conjecturas no que tange às possíveis relações estabelecidas com os trabalhadores de uma Organização Social de Saúde (OSS), que, por sua vez, segundo a nossa proposta, é produto de uma racionalidade governalmental condizente à reprodução de relações de trabalho precárias e flexíveis.

\section{A precariedade laboral nas organizações sociais de saúde: o controle biopolítico desencadeador da flexibilidade das relações de trabalho}

Trataremos da racionalidade que se manifesta sobre a população sob a forma de intervenção biopolítica e que se coaduna com a proposta deste artigo pela articulação das inovações organizacionais e, especialmente, das organizações não governamentais, advindas da Reforma do Estado, com a alteração no modo de produção e nas relações do trabalhador com o seu trabalho.

Nesse sentido, deve-se mencionar que entre as transformações ocorridas no mundo do trabalho e em relação ao próprio sujeito trabalhador, na transição de uma sociedade industrial para a pós-industrial, ressaltamos a influência de uma economia do imaterial que resultou em uma questão essencial a nossas reflexões: na mudança de uma economia voltada para a produção do capital para outra que se caracteriza por sua dimensão biopolítica.

A expressão "biopolítica", cunhada por Michel Foucault pela primeira vez na conferência de 1974, alude a uma forma de exercício do poder soberano que, a partir do final do século XVIII, passou a constituir os estados modernos, tendo como alvo não o território, mas a população.

Consiste, portanto, em estratégias caracterizadas por um conjunto de tecnologias e de políticas institucionais voltadas especificamente para o controle de diversos aspectos da vida e do corpo, do controle da natalidade à vacinação contra epidemias (FOUCAULT, 2005, p. 289).

Sobre a correlação entre a biopolítica e o biopoder, sendo este definido como "[...] o conjunto dos mecanismos pelos quais aquilo que, na espécie humana, constitui suas características biológicas fundamentais vai poder entrar numa política, numa estratégia política, numa estratégia geral de poder" (FOUCAULT, 2008b, p. 3), pode-se dizer que se trata de conceitos que se complementam, sobretudo se considerarmos que " [...] quando a vida natural passou a fazer parte do biopoder exercido pelo Estado, a política deixou de ser tão somente política para ser pensada à luz da sofisticação de mecanismos biopolíticos (BUSSINGUER; SALLES, 2012, p. 167).

A biopolítica é um exercício político sobre a vida pensado a partir das tecnologias de poder estatal, e, nessa perspectiva, sua manifestação pode ser observada em diversos âmbitos da vida e dos problemas da população, dentre os quais destacaremos o contexto dos trabalhadores da saúde, uma vez que

[...] o cotidiano da saúde não é isento da incidência de mecanismos biopolíticos que proporcionam o controle sobre a vida. Pelo contrário, a manifestação biopolítica sobre a vida, isto é, exercida por meio de mecanismos de biopoder, resulta, no 
cotidiano da saúde, num impacto político abrangente sobre a vida, uma vez que não se restringe aos indivíduos diretamente afetados, incidindo, inclusive, sobre aqueles que se encontram envolvidos com a vida humana submetida ao controle em questão, fato que não deve ser desconsiderado. (BUSSINGUER; SALLES, 2012, p. 169).

Nesse sentido, afirma-se que o controle biopolítico que impacta a vida do trabalhador da saúde, justamente pela complexidade que envolve o campo, também resultará em efeitos sobre a vida daqueles que se relacionam diretamente com eles, a exemplo dos usuários de serviços de saúde.

Corroborando a aplicação da biopolítica no contexto da saúde do trabalhador, Faria e Bussinguer (2016, p. 134) afirmam que "[...] a mais discutível estratégia tem sido a tendência do empregador em querer controlar o comportamento do empregado, mesmo de forma extraprofissional", como forma de elidir a responsabilidade do empregador no que se refere às doenças que acometem o empregado.

Aplicando a problematização deste artigo, outro exemplo a ser mencionado consiste na incorporação da flexibilidade nas relações laborais que se desenvolvem nas Organizações Sociais de Saúde (OSSs) e que alicerça o vínculo supostamente celetista que as sustenta e pode ser analisada sob a ótica de um mecanismo de controle biopolítico exercido sobre a vida dos trabalhadores.

Do mesmo modo, a utilização de contratos de gestão contendo cláusulas genéricas no que tange ao rol de serviços a serem prestados pela entidade gestora, denunciando sua frágil regulação, também pode ser apontada como estratégia biopolítica determinada pelo poder econômico e que não se coaduna com a efetivação do direito fundamental social ao trabalho.

Além destas, outras tantas: as contratações por determinação temporária, a terceirização, as variações de contratações irregulares, entre tantas outras variáveis que assumem como produto final a forma da precarização laboral e que fomentam a insegurança jurídica, a instabilidade empregatícia, o estímulo à alta rotatividade da mão de obra e a existência de relações de trabalho cada vez mais flexíveis.

Pertinente mencionar nesse contexto as contribuições de Bauman (2001) acerca do trabalho flexível como corolário da modernidade líquida. O autor apresenta a busca pela flexibilidade como produtora de novas estruturas de poder e de controle. Daí dizer-se que a flexibilidade laboral corresponde a novas possibilidades de exercício de controle produzidas pelas instâncias econômicas.

Ao referir-se ao trabalho precário, remete-se àquele "[...] trabalho incerto, imprevisível, e no qual os riscos empregatícios são assumidos principalmente pelo trabalhador, e não pelos seus empregados ou pelo governo." (KALLEBERG, 2009, p. 21).

De acordo com a Organização Internacional do Trabalho (OIT) (2017), o trabalho precário é aquele que, opondo-se ao trabalho decente, pode apresentar-se sob as seguintes dimensões: "1) insegurança no mercado de trabalho; 2) insegurança no trabalho; 3) insegurança de emprego; 4) 
insegurança de segurança e saúde; 5) insegurança de reprodução de experiência; 6) insegurança de renda; 7) insegurança de representação." (KALLEBERG, 2009, p. 21).

Nota-se que a "insegurança" pode ser apontada como um vocábulo importante para a definição da precariedade, que pode se manifestar, como já dito, de modo variado e em diversos contextos: da falta de oportunidades de emprego no mercado de trabalho à insegurança legislativa representada tanto pela frágil tutela dispensada ao trabalhador quanto por sua ausência.

Em todo caso, pretende-se enfatizar que se trata invariavelmente de questões políticas e de decisões biopolíticas que atingem a subjetividade do trabalhador e que podem interferir na qualidade dos serviços a serem desempenhados.

Ainda nesse contexto, pertinente à aplicação da Teoria do Capital Humano, introduzida por Foucault ao descrever a governamentalidade neoliberal norte-americana, uma vez que com esse aporte teórico o referido autor nos inspira a contextualizar a orientação de políticas para o investimento em capital humano como um empreendimento biopolítico.

Corroborando a dimensão imaterial do trabalho humano, a aplicação da teoria em questão na vida laboral sugere o dimensionamento dessa economia do imaterial na vida do trabalhador sob a forma de mecanismo biopolítico que se manifesta mediante o controle da subjetividade do obreiro.

O trabalhor, enquadrado como sujeito na governamentalidade neoliberal, assumindo a forma de uma empresa, cuja dimensão destaca seu enquadramento como recurso humano, integra um contexto no qual as relações humanas se estabelecem sob os moldes comerciais e, portanto, expressam-se concorrencialmente.

Sendo ele - o trabalhador - um capital humano, o investimento a ser realizado para o aprimoramento de suas aptidões técnicas e intelectuais representa um reforço à lógica de economicidade e competitividade que o orienta. Não havendo como optar por não aderir a esse novo padrão de relacionamento, o obreiro incorpora e reproduz a racionalidade neoliberal em suas práticas, sob pena de não agregar valor ao seu capital e, consequentemente, correr o risco do desemprego. A esse novo padrão de relacionamento do trabalhador com o seu trabalho atribuímos também a dimensão de uma biopolítica a ser incorporada como forma de estímulo à produtividade e à qualificação profissional.

Vimos que a Reforma do Estado, na mesma medida em que foi responsável pela inauguração de organismos que se caracterizam por estabelecer um novo padrão de relacionamento com Estado, também contribuiu para a formação de um ambiente propício para que novas relações entre trabalhadores fossem firmadas. E, assim, notamos, nas novas técnicas de gestão implementadas pelo Estado, o exercício de um poder sobre a vida dos trabalhadores (biopoder) que, enquanto sujeitos, direta on indiretamente, submetidos ao controle estatal, passa a se manifestar sob a forma de politização da vida, de biopolítica. 
Com tais articulações buscamos problematizar as formas de manifestação de mecanismos biopolíticos, orientados pela razão governamental neoliberal, nas relações de trabalho no contexto das OSSs.

À medida que compreendemos o governo como uma atividade que não se restringe ao Estado, mas que nele manifesta o seu exercício político, tornamo-nos capazes de vislumbrar no interior de organismos governamentais, ou mesmo fora deles, a observância à orientação da racionalidade que opera como regime de verdade vigente, no caso, a governamentalidade neoliberal.

Nessa perspectiva, consideramos que a governamentalidade neoliberal é vislumbrada como racionalidade que orienta o exercício do poder político exercido pelo governo, e, sob essa ótica, as OSSs são assumidas como estratégia de gestão e, mais que isso, da atuação de gestores dessas entidades privadas sem fins lucrativos na execução de práticas laborais precarizantes.

Estamos tratando de uma racionalidade de governo que na medida em que assume a ordem econômica como prioridade de gestão dirige suas ações ao mercado, fixando, estabelecendo, firmando a centralidade de seu interesse, qual seja: o capital.

Nesse ponto, uma importante observação consiste em reconhecer a existência de capitais múltiplos que são objeto de anseio social. Há o capital econômico, o capital político, o capital social, o capital intelectual, o capital cultural e o capital humano.

Tal consideração é fundamental para que compreendamos que, a despeito de serem as OSSs entidades privadas sem fins lucrativos, o capital que as movimenta e fomenta não é representado apenas pela dimensão econômica. $\bigcirc$ interesse nessa modalidade de gestão envolve questões um tanto quanto mais complexas, pois pressupõe relações de interesse entre o público e o privado que induzem relações de poder.

Para além do volume de recursos financeiros, movimentos por tais entidades que, paradoxalmente, não se dirigem ao lucro, o estímulo à adesão dessa estratégia de gestão também decorre de outros importantes fatores de influência. Basta considerarmos que sua adesão, em paridade com o compromisso de "enxugamento" da burocracia, tem como desdobramento, direto ou indireto, a afetação do capital humano mediante a concretização do anseio de redução de custos com o quadro de pessoal.

Nessa perspectiva, a fragilidade de vínculos no interior das OSSs passa a ser compreendida como uma alternativa coerente com uma política de gestão de recursos humanos que, embora não tenha o lucro como um fim declarado, traz como consequência a utilização de uma força de trabalho de baixo custo, quando comparado ao de um servidor público.

\section{Considerações finais}

As contribuições analíticas oferecidas pelo referencial teórico adotado - a governamentalidade neoliberal - nos permitiu contextualizar a tendência expansionista de práticas 
e de políticas acentuadoras da instabilidade dos vínculos de trabalho nas Organizações Sociais de Saúde (OSS's).

Pela articulação da governamentalidade neoliberal com a Reforma do Estado brasileiro dos anos 1990, vislumbramos, entre os projetos que se sucederam como corolário das medidas implementadas naquele período, a legitimação institucional das OSSs por meio do sancionamento de legislação específica (Lei n. 9637/1998).

Nesse contexto, as OSSs foram apresentadas como estratégia de gestão do governo e, consequentemente, dos aparelhos que o envolvem, a serviço da lógica neoliberal, viabilizadora de controles biopolíticos no contexto laboral, mediante a imposição do governo do mercado.

Michel Foucault nos inspira a compreender o relacionamento entre o Estado e o mercado a partir da racionalidade neoliberal, tendo em vista sua operação como diretriz da ação governamental mediante um conjunto de técnicas específicas viabilizadoras da gestão e do controle da população. $\mathrm{Na}$ medida em que se reconhece que a racionalidade do governo opera segundo táticas apropriadas ao alcance de fins específicos, justifica-se a elaboração de uma série de políticas e de controles biopolíticos em atenção às regras disciplinadoras do governo, conjecturando um elaborado arranjo estatal racionalmente direcionado.

Tais ponderações foram viabilizadas tanto pela análise de características advindas do estudo realizado por Michel Foucault acerca da governamentalidade neoliberal aplicada na Alemanha - ordoliberalismo alemão - quanto pela aplicação do seu conceito de biopolítica, possibilitando o dimensionamento da influência de seu pensamento para a compreensão, bem como para a adoção de práticas estimuladoras da precarização laboral.

Pensar o neoliberalismo como uma governamentalidade, na esteira de Foucault, implica reconhecer que a razão econômica, sua lógica e suas técnicas assumiram a centralidade do governo como princípio e fim de seu exercício. Nessa perspectiva, o relacionamento entre a governamentalidade neoliberal e a precarização laboral no interior das OSSs tem como pressuposto a constatação de uma razão de governo influenciadora da compreensão e da adoção de práticas estimuladoras da fragilidade de vínculos de trabalho. Mais que isso, tem como premissa a assunção das OSSs como estratégia de governo articulada, na década de 1990, no contexto da reforma econômica e administrativa do aparelho estatal.

A partir da aproximação entre as características da governamentalidade neoliberal e a onda de reformas realizadas nos anos 1990, identificamos a interligação com uma razão de governo neoliberal que permite compreender as OSSs como instrumento, como estratégia, como aparelhagem técnica de gestão do Estado a serviço da lógica do mercado. Para tanto, temos como pressuposto o reconhecimento de que as OSSs foram uma técnica de gestão, uma estratégica de governo viabilizadora de controles biopolíticos no contexto laboral, mediante a imposição do governo do mercado.

Considera-se, portanto, que a fragilidade dos vínculos trabalhistas na sociedade contemporânea pode ser analisada como produto de práticas e políticas características da 
racionalidade de governo neoliberal e, consequentemente, a formalização de vínculos precários de trabalho nas OSSs pode ser apontada como um subproduto dessa conjuntura.

Consoante às proposições apresentadas neste artigo, as relações de mercado, decorrentes da governamentalidade neoliberal, potencialmente, prestam-se à (re)produção de relações precárias e flexíveis.

A fragilidade de vínculos no interior das OSSs passa a ser compreendida como uma alternativa coerente com uma política de gestão de recursos humanos que, embora não tenha o lucro como um fim declarado, traz como consequência a utilização de uma força de trabalho de baixo custo quando comparada ao de um servidor público.

Sob essa ótica, o trabalhador, enquadrado ora como um capital humano, ora como um recurso humano, é um produto direto da indexação do governo e da sociedade pelo modelo da empresa, levando-nos a questionar essa governamentalidade que submete os direitos fundamentais à saúde e ao trabalho à lógica das trocas concorrenciais e comerciais.

\section{Referências}

ANTUNES, Ricardo. Os modos de ser da informalidade: rumo a uma nova era da precarização estrutural do trabalho? Serviço Social \& Sociedade, São Paulo, n. 107, p. 405-419, jul./set. 2011.

ANTUNES, Ricardo; ALVES, Giovanni. As mutações no mundo do trabalho na era da mundialização do capital. Educação \& Sociedade, Campinas, v. 25, n. 87, p. 335-351, maio/ago. 2004. Disponível em: <http://www.scielo.br/pdf/\%0D/es/v25 n87/21460.pdf>. Acesso em: 10 jan. 2017.

ANTUNES, Ricardo; POCHMANN, Marcio. A desconstrução do trabalho e a explosão do desemprego estrutural e da pobreza no Brasil. In: CIMADAMORE, Alberto D.; CATTANI, Antonio David. Produção de pobreza e desigualdade na América Latina. Porto Alegre: Tomo Editorial, 2007.

ARIAS, Eluiza Helena Leite et al. Gestão do trabalho no SUS. Cadernos RH Saúde, Brasília, v. 3, n. 1, p. 119-124, mar. 2006.

ASSUNÇÃO, Ada Ávila; JACKSON FILHO, José Marçal. Transformações do trabalho no setor saúde e condições para cuidar. In: ASSUNÇÃO Ada Ávila; BRITO, Jussara (Org.). Trabalhar na saúde: experiências cotidianas e desafios para a gestão do trabalho e do emprego. Rio de Janeiro: Fiocruz, 2011.

BAHIA, Ligia. A privatização no sistema de saúde brasileiro nos anos 2000: tendências e justificação. In: SANTOS, Nelson Rodrigues dos Santos; AMARANTE, Paulo Duarte de Carbalho (Org.). Gestão pública e relação público privado na saúde. Rio de Janeiro: Cebes, 2010.

BAHIA, Ligia; SCHEFFER, Mario. Representação política e interesses particulares na saúde: a participação de empresas de planos de saúde no financiamento de campanhas eleitorais em 2014. Relatório de pesquisa. 25 fev. 2015. Disponível em: <http://cebes.org.br/site/wp-content/uploads/2015/03/ Planos-de-Saude-e-Eleicoes-FEV-2015.pdf>. Acesso em: 26 jan. 2017.

BAUMAN, Zygmunt. Modernidade líquida. Rio de Janeiro: Zahar, 2001. 
BRASIL. Constituição. República dos Estados Unidos do Brasil. Rio de Janeiro, 1934. Disponível em: <http://www2.camara.leg.br/legin/fed/consti/1930-1939/constituicao-1934-16-julho-1934-365196-publicacaooriginal-1-pl.html>. Acesso em: 17 jul. 2018.

BUSSINGUER, Elda Coelho de Azevedo; ROCHA, Sarah Hora. O assédio moral laboral no setor da saúde. In: BUSSINGUER, Elda Coelho de Azevedo (Org.). Princípios constitucionais e direito à vida: uma experiência integrativa de ensino e pesquisa. Curitiba: CRV, 2014. p. 125-134.

BUSSINGUER, Elda Coelho de Azevedo; SALLES, Shayene Machado. O Contexto biopolítico do prolongamento artificial da vida de pacientes terminais à luz da perspectiva de Giorgio Agamben. In: BUSSINGUER, Elda Coelho de Azevedo (Org.). Direitos e deveres fundamentais. 1 ed. Rio de Janeiro: Lumen Juris, 2012. p. 1-260.

BRESSER-PEREIRA, Luiz Carlos Bresser. Administração pública gerencial: estratégia e estrutura para um novo Estado. Brasília: ENAP, 2001.

CANDIOTTO, Cesar. A governamentalidade política no pensamento de Foucault. Filosofia Unisinos, v. 11, n. 1, p. 33-43, jan./abr. 2010.

CARDOSO JUNIOR, José Celso. Macroeconomia e mercado de trabalho no Brasil: trajetória recente e tendência aparente. In: OBSERVATÓRIO DE RECURSOS HUMANOS EM SAÚDE (NESP/ CEAM/UnB). Conjuntura do emprego em saúde na primeira metade da década de 2000. Brasília: UnB, 2006. Disponível em: <http://www.observarh.org.br/observarh/repertorio/Reper torio_ObservaRH/NESP-UnB/Macroeconomis_mercado_trabalho.pdf>. Acesso em: 30 out. 2016.

COSTA, Sylvio de Sousa Gadelha. Governamentalidade neoliberal, teoria do capital humano e empreendedorismo. Educação \& Realidade, v. 34, n. 2, p. 171-186, maio/ago. 2009. Disponível em: <http://www.seer.ufrgs.br/educacao erealidade/article/viewFile/8299/5537>. Acesso em: 25 nov. 2016.

DARDOT, Pierre; LAVAL, Christian. A nova razão do mundo: ensaio sobre a sociedade neoliberal. São Paulo: Boitempo, 2016.

ESCOREL, Sarah; TEIXEIRA, Luiz Antonio. História das política de saúde no Brasil de 1822 a 1963: do império ao desenvolvimentismo populista. In: GIOVANELLA, Ligia et al. (Org.). Políticas e sistemas de saúde no Brasil. Rio de Janeiro: Editora Fiocruz, 2012. p. 279-322.

FARIA, Ana Paula Rodrigues Luz; BUSSINGUER, Elda Coelho de Azevedo. Bioética da libertação e saúde do trabalhador: a (in)admissibilidade dos exames genéticos preditivos nas relações de trabalho. São Paulo: Ltr, 2016.

FLEURY, Sonia; OUVERNEY, Assis Mafort. Política de saúde: uma política social. In: GIOVANELLA, Lígia et al. (Org.). Políticas e sistema de saúde no Brasil. Rio de Janeiro: Ed. Fiocruz, 2008. p. 23-64.

FOUCAULT, Michel. Em defesa da sociedade: curso no Collège de France (1975-1976). São Paulo: Martins Fontes, 2005.

FOUCAULT, Michel. Nascimento da biopolítica. São Paulo: Martins Fontes, 2008a.

FOUCAULT, Michel. Segurança, território e população. São Paulo: Martins Fontes, 2008b. 
GARRAFA, Volnei. Reflexão sobre políticas públicas brasileiras de saúde à luz da bioética. In: FORTES, Paulo Antônio de Carvalho Fortes; ZOBOLI, Elma Lourdes Campos Pavone (Org.). Bioética e saúde pública. São Paulo: Loyola, 2003.

GIRARDI, Sábado Nicolau; CARVALHO, Cristiana Leite. Configurações do mercado de trabalho dos assalariados em saúde no Brasil. Formação, Brasília, v. 2, n. 6, p. 15-35, 2002.

KALLEBERG, Arne L. O crescimento do trabalho precário: um desafio global. Revista brasileira Ciências Sociais, v. 24, n. 69, p. 21-30, 2009. Disponível em: <http://www.scielo.br/scielo.php?script=sci_arttext\&pid=S0102-69092009000100002 >. Acesso em: 13 set. 2016.

KROHLING, Aloísio. Direitos humanos fundamentais: diálogo intercultural e democracia. São Paulo: Paulus, 2009.

LEITE, Carlos Henrique Bezerra. Direitos humanos. 2. ed. Rio de Janeiro: Lumen Juris, 2011.

MACHADO, Maria Helena. Gestão do Trabalho em Saúde no contexto de mudanças. Revista de Administração Pública (RAP), v. 34, n. 4, 2000a. Disponível em: <http://bibliotecadigital.fgv.br/ojs/ index.php/rap/article/view/6295/4885>. Acesso em: 17 nov. 2016.

MACHADO, Maria Helena. Gestão do trabalho em saúde. In: PEREIRA, Isabel Brasil; LIMA, Júlio César França. Dicionário da educação profissional em saúde. 2. ed. Rio de Janeiro: Fundação Oswaldo Cruz, 2009. Disponível em: <http://www.sites.epsjv.fiocruz.br/dicionario/verbetes/gestrasau. html>. Acesso em: 17 nov. 2016.

MACHADO, Maria Helena; OLIVEIRA, Eliane dos Santos de; MOYSES, Neuza Maria Nogueira. Tendências do mercado de trabalho em saúde no Brasil. In: PIERANTONI, Celia; DAL POZ, Mario Roberto; FRANÇA, Tania (Org.). O Trabalho em saúde: abordagens quantitativas e qualitativas. 1. ed. Rio de Janeiro: CEPESC, UERJ, 2011, v. 001, p. 103-116.

MACHADO, Maria Helena. Perfil dos médicos e enfermeiros do Programa Saúde da Família no Brasil: relatório final. Brasília: Ministério da Saúde, 2000b. v. 1.

MARTINS, Maria Inês Carsalade; MOLINARO, Alex. Reestruturação produtiva e seu impacto nas relações de trabalho nosservulos públicos de saúde no Brasil. Ciência \& Saúde Coletiva, v. 18, n. 6, p. 1667-1676, 2013.

ORGANIZAÇÃO DAS NAÇÕES UNIDAS. Pacto Internacional de Direitos Econômicos sociais e culturais (1976). Disponível em: <http://www.dhnet.org.br/direitos/sip/onu/doc/pacto1.htm>. Acesso em: 17 jul. 2018.

ORGANIZAÇÃO INTERNACIONAL DO TRABALHO. Organização Internacional do Trabalho promovendo o trabalho decente: o que é trabalho decente. Disponível em: <http://www.oitbrasil.org.br/ content/o-que-e-trabalho-decente>. Acesso em: 26 jan. 2017.

PERIM, Maria Clara Mendonça. Organizações Sociais e a Diretriz da Complementaridade: desafios da participação social na saúde. 1. ed. Curitiba: CRV, 2014.

PIERANTONI, Célia Regina; VARELLA, Thereza Christina. Mercado de trabalho: revendo conceitos e aproximando o campo da saúde. A década de 90 em destaque. Physis Revista de Saúde Coletiva, Rio de Janeiro, v. 18, n. 3, p. 521-544, 2008. 
PIOVESAN, Flávia; VIEIRA, Renato Staziola. Justiciabilidade dos direitos sociais e econômicos no Brasil: desafios e perspectivas. Araucaria, revista iberoamericana de filosofia, política e humanidades, a. 8, n. 15, $1^{\circ}$ sem. 2006. Disponível em: <http://institucional.us.es/araucaria/nro15/nro15.htm>. Acesso em: 21 abr. 2013.

RIBEIRO JÚNIOR, Humberto. Governamentalidade neoliberal e biopolítica da exceção: as intervenções biopolíticas sobre a população no contexto da arte de governar neoliberal. 2013. 234 p. Tese (Doutorado em Ciências jurídicas e sociais)-Universidade Federal Fluminense, Rio de Janeiro, 2013.

RIZZOTTO, Maria Lúcia Frizon. Neoliberalismo e saúde. In: PEREIRA, Isabel Brasil; LIMA, Júlio César França (Org.). Dicionário da educação profissional em saúde. 2. ed. Rio de Janeiro: Fundação Oswaldo Cruz, 2009. Disponível em: <http://www.sites.epsjv.fiocruz.br/dicionario/verbetes/gestrasau.html>. Acesso em: 17 nov. 2016.

ROCHA, Sarah Hora. Violência e assédio moral em face dos exercentes da enfermagem: uma análise das relações de poder estabelecidas no ambiente laboral no setor saúde. 2015. 134 p. Dissertação (Mestrado em Direitos e Garantias Fundamentais)-Faculdade de Direito de Vitória, Vitória, 2015.

SANSON, Cesar. Trabalho e subjetividade: da sociedade industrial à sociedade pós-industrial. 2009. 156 p. Tese (Doutorado em Sociologia)-Universidade Federal do Paraná, Paraná, 2009.

SANTOS, Boaventura de Sousa. Poderá o direito ser emancipatório? Revista Crítica de Ciências Sociais, n. 65, p. 3-76, maio 2003.

SARMENTO, Daniel. Interesses público vs. Interesses privados na perspectiva da teoria e da filosofia constitucional. In: SARMENTO, Daniel (Org.). Interesses públicos versus interesses privados: desconstruindo o princípio da supremacia do interesse público. Rio de Janeiro: Lumen Juris, 2007.

SOUTO MAIOR, Jorge Luiz. A Fúria. Revista LTR, São Paulo, v. 66, n. 11, p. 1287-1309, 2002.

WANDELLI, Leonardo Vieira. O direito fundamental ao conteúdo do próprio trabalho: uma reconstrução normativa do direito ao trabalho. Espaço Jurídico Journal of Law, Joaçaba, v. 17, n. 3, p. 1013-1036, set./dez. 2016.

Data da submissão: 04 de abril de 2018 Avaliado em: 10 de abril de 2018 (AVALIADOR A) Avaliado em: 10 de abril de 2018 (AVALIADOR B) Avaliado em: 10 de abril de 2018 (AVALIADOR C) Aceito em: 12 de abril de 2018 